Mitchell Hamline School of Law

Masthead Logo Mitchell Hamline Open Access

Faculty Scholarship

2010

\title{
Remodeling the Classified Information Procedures Act (CIPA)
}

Afsheen John Radsan

Mitchell Hamline School of Law, john.radsan@mitchellhamline.edu

Publication Information

32 Cardozo Law Review 437 (2010)

\section{Repository Citation}

Radsan, Afsheen John, "Remodeling the Classified Information Procedures Act (CIPA)" (2010). Faculty Scholarship. 451.

https://open.mitchellhamline.edu/facsch/451 


\title{
Remodeling the Classified Information Procedures Act (CIPA)
}

\begin{abstract}
The intelligence community and the law enforcement sector are supposed to be working closely to keep us all safe from terrorists and other dangers. The benefits of this cooperation should not be frittered away by unnecessary burdens in trying suspected terrorists in civilian courts. If the executive branch is to be kept away from the dark side of counterterrorism, the courts, Congress, or a combination of the two should modernize their approach to alignment, to Section 6 of Classified Information Procedures Act, and to closed portions of trials.
\end{abstract}

First, a prosecutor's discovery obligations should apply to the intelligence community only when spymasters have most actively participated in the investigation. When defining "most actively" and in determining who falls within the prosecution unit, all three branches of government should err toward non-alignment. The recent creep toward conceding alignment on all cases since 9/11 should stop.

Second, courts should be less inclined to admit top-secret information into trial than information at a lower level of classification. The more sensitive the information, the more leeway courts should give prosecutors in proposing substitutions and summaries. The common sense that probably fills the gaps of CIPA practice, squeezing around cases and the statute, should be formalized by an update of CIPA.

Third, it should be possible to close portions of trials to all but the judge, jury, and the parties to the case when especially sensitive information is being presented. These limited closures will allow courts, as a compensating benefit, to lean toward defendants on Section 6 decisions as to the use of classified information at trial. By this compensation, the either/or of full disclosure versus complete suppression is traded for a range of options.

CIPA is showing its age. Even so, because its foundation is solid, it does not require a tear down as much as a remodeling. In at least three areas - alignment, Section 6, and closed portions of trials - our nation deserves a better resolution between the conflicting interests of prosecutors and spymasters.

\section{Keywords}

CIPA, Civilian trials, Military commissions, Classified Information Procedures Act, Intelligence community, CIA, FBI, Law enforcement, Discovery, Brady, Terrorism, Counterterrorism

\section{Disciplines}

National Security Law 


\title{
REMODELING THE CLASSIFIED INFORMATION PROCEDURES ACT (CIPA)
}

\author{
Afsheen John Radsan*
}

INTRODUCTION

\section{A. The Tensions Between Intelligence and Law Enforcement}

Khaled Sheikh Mohammed (KSM) is the highest-level member of al Qaeda captured since 9/11.1 On November 14, 2009, six years after KSM's capture in Pakistan, Attorney General Eric Holder designated KSM, along with four other suspected terrorists, for trial in the Southern District of New York. ${ }^{2}$ The consequences of Holder's attempt at transparent justice are not yet clear.

If a high-level terrorist eventually pleads guilty or is convicted in civilian court, the Obama Administration will use that result to justify handling other suspected terrorists the same way. That justification would be unfortunate because guilty verdicts, if they do occur in civilian court for members of al Qaeda, will be strokes of luck rather than the benefit of sound strategy. From arraignment to jury trial to sentencing, handling high-level terrorists in civilian court presents profound problems. The transparency of civilian justice cannot always be reconciled with the secrecy of intelligence activities.

How much access will terrorists and their defense lawyers be given to CIA records and to other files within the American intelligence community? What classified information will be put on the public record? To what extent will witnesses discuss the circumstances of KSM's capture, detention, and interrogation? Will any CIA employees

* Professor, William Mitchell College of Law (john.radsan@wmitchell.edu). Professor Radsan is a former federal prosecutor and a former CIA lawyer. He thanks Benjamin Canine, Brian Carter, Sarah McBroom and Michael Weinbeck for research assistance.

1 See Erik Eckholm, Pakistanis Arrest Qaeda Figure Seen as Planner of 9/11, N.Y. TIMES, Mar. 2, 2003, at A1 (describing KSM's capture and suggesting he "may be the most important and is certainly the most feared" of the al Qaeda agents captured since 9/11).

2 Charlie Savage, U.S. to Try Avowed 9/11 Mastermind Before Civilian Court in New York, N.Y. TIMES, Nov. 14, 2009, at Al (describing Holder's decision to prosecute KSM in federal court). 
take the stand? The Classified Information Procedures Act (CIPA), which regulates the disclosure and use of classified information in federal criminal cases, purports to answer these questions for civilian court. ${ }^{3}$ But CIPA, under current practices, is not up to the task. For this reason, I argue that if suspected terrorists are to be tried in federal court, the CIPA statute and other trial practices must be updated to sustain and to encourage greater collaboration between American intelligence agencies and law enforcement.

KSM, no matter one's perspective, is a tough case for American justice. Snatched from his sleep in Pakistan in 2003, KSM was transferred with the help of foreign security services to various secret sites for enhanced interrogations outside the United States. CIA interrogators used the "waterboard"-a sort of simulated drowning - on him 183 times. ${ }^{4}$ By 2006, as a result of President Bush's lobbying for the Military Commissions Act, KSM was transferred to Guantanamo Bay, Cuba. There, the Bush Administration tried to deal with him by military commission. But the Administration did not complete the process before President Obama took office in 2009.

If my predictions are correct, handling al Qaeda members in civilian court will come at great cost to intelligence sources and methods. These cases highlight the urgency of adjusting CIPA to handle secrets in public trials. If I am incorrect (and if a high-level terrorism case in civilian court is not a disaster for the intelligence community), then the Obama Administration will have no principled excuse for trying any suspected terrorists by alternative adjudication.

CIPA is not only about terrorists. Before $9 / 11$, the most prominent cases under CIPA involved double agents; Ames, ${ }^{5}$ Hanssen, ${ }^{6}$ Nicholson, ${ }^{7}$ and other traitors come to mind. Even so, classified information has also affected narcotics, fraud, and bribery cases. Regardless of whether the prosecution is for espionage or terrorism, the complications that stem from handling classified information in civilian court sometimes cause the prosecutor to drop the criminal charges. ${ }^{8}$

3 Classified Information Procedures Act (CIPA), 18 U.S.C. app. $3 \S \S 1-16$ (2006).

4 See Scott Shane, Waterboarding Used 266 Times on 2 Suspects, N.Y. TIMES, Apr. 20, 2009 , at A1.

5 See generally PETE EARLEY, CONFESSIONS OF A SPY: THE REAL STORY OF ALDRICH AMES (G.P. Putnam's Sons 1997). Aldrich Ames was convicted of spying in 1994 after he admitted to providing the KGB with CIA intelligence in return for over four million dollars. Id.

6 See generally Adrian Havill, THE SPY Who Stayed out IN the COLd: THE SECRET LIFE OF FBI DOUBLE AGENT ROBERT HANSSEN (2001). In 2001, Robert Hanssen pleaded guilty to twenty counts of espionage after fifteen years of disclosing sensitive information to the Soviets and Russians. Id.

7 See generally Tim Weiner, C.I.A. Officer Admits Spying for Russians, N.Y. TIMES, Mar. 4, 1997, at A14. Harold Nicholson, the highest ranking CIA officer ever charged with espionage, spied for the Russians from 1994 to 1997 . Id.

8 The Iran-Contra prosecution of Joseph Fernandez, a CIA chief in Costa Rica, is one example. United States v. Fernandez, 913 F.2d 148 (4th Cir. 1990). CIPA forced the trial court 
Other times, the complications are resolved and a conviction obtained. ${ }^{9}$ (And sometimes, after hearing from the intelligence community in private, federal prosecutors decide not to bring criminal charges at all.) Overall, whether and how the complications are resolved depends on the case and the sensitivity of the information to be disclosed. For terrorism and other cases, CIPA is a place where the secrecy necessary to protect sources and methods collides with the transparency at the core of American justice.

The prosecution of Zacarias Moussaoui is another example of a terrorism case that relied on CIPA-style procedures to balance the values of secrecy and transparency. ${ }^{10}$ Arrested before 9/11, but sentenced after 9/11, Moussaoui straddled two eras in American counterterrorism. Nearly five years after his indictment in 2001, after many tense exchanges between prosecutors and the intelligence community, and after appeals between the district court and the Fourth Circuit, one holdout juror spared Moussaoui's life." Moussaoui, no longer the center of a media circus, spends the rest of his life in a supermax facility in Florence, Colorado. In the aftermath, scholars debate whether United States v. Moussaoui shows that criminal justice

to dismiss charges against Fernandez because the intelligence community would not reveal classified information the court determined was necessary to Fernandez's defense. Id.

9 See, e.g., Carol D. Leonnig \& Amy Goldstein, Libby Guilty on 4 of 5 Counts; Former Cheney Aide Convicted of Lying About His Role in Leak, WASH. POST, Mar. 7, 2007, at A1. Prosecutor Patrick Fitzgerald cleared CIPA hurdles and obtained convictions against "Scooter" Libby for obstructing justice and making false statements in an investigation related to the "outing" of CIA analyst Valerie Plame. Id.

10 United States v. Moussaoui, 282 F. Supp. $2 d 480$ (E.D. Va. 2003), aff'd in part on reh'g, 382 F.3d 453 (4th Cir. 2004), cert. denied, 544 U.S. 931 (2005). Moussaoui, for a while believed to be the "twentieth hijacker," was arrested before the 9/11 attacks and then charged in civilian court with conspiracy to commit international terrorism and other crimes related to $9 / 11$. Moussaoui claimed he was not involved in $9 / 11$ and did not know about the attacks. Id. at 484 n.11. He did admit, however, that he was prepared for follow-up attacks. Other high-level al Qaeda detainees, during interrogations at ClA black sites, made exculpatory comments that supported Moussaoui's claim that he knew nothing of $9 / 11$. 382 F.3d at 473-74. The government provided classified discovery to Moussaoui's lawyers, who had security clearances, but not to Moussaoui himself. Upon the defense's request, the trial court ordered the government to give Moussaoui access to the high-level detainees via a video feed in a remote location. The government refused, preferring instead to take its CIPA lumps. In an expected move, the trial court eliminated the death penalty as a possible sentence in the case. The government, not satisfied with the prospect of a life sentence for Moussaoui, filed an interlocutory appeal under CIPA $\S 7$. The Fourth Circuit, more receptive than the trial court to the government's national security arguments, ruled that written statements based on responses to interrogators from the intelligence community were adequate substitutes for detainee depositions that would have included the parties. For this reason, the Fourth Circuit remanded the case to the district court to manage those substitutions. Id. at 477-80. Moussaoui appealed, and the Supreme Court denied his petition for review. Back in district court, Moussaoui-in a surprise to all-pleaded guilty, an act that obviated any separate CIPA issues for the guilt phase of the case. United States v. Moussaoui, 591 F.3d 263, 271 (4th Cir. 2010).

11 Timothy Dwyer, One Juror Between Terrorist And Death; Moussaoui Foreman Recalls Frustration, WASH. POST, May 12, 2006, at Al. 
can handle terrorism trials or whether the "mess from Minnesota" underscores the need for alternative adjudication. ${ }^{12}$ No matter one's opinion on the specifics of Moussaoui, that case illustrates the challenges for spymasters and prosecutors in handling terrorism in civilian courts. As to other members of al Qaeda in American custody, the suspects' rights to due process often conflict with what is necessary to protect national security.

Even in the struggle against international terrorists, sharing information has not always been easy for the intelligence and law enforcement sectors. This difficulty stems, in part, from distinct institutional cultures. CIA officers and FBI agents, with different missions and separate training, see the world through distinct lenses. The CIA gathers intelligence for policymakers under a cloak of secrecy, while the FBI gathers evidence likely to see daylight in a public trial. The CIA operates mainly overseas while the FBI operates mainly in the United States. For the nation's security from foreign and domestic foes, the CIA and the FBI have improved and should continue to improve their cooperation. ${ }^{13}$ But if CIPA does not provide realistic protection of intelligence sources and methods, public terrorism trials during the Obama era will impede cooperation between the CIA and the FBI.

Much has been done to facilitate cooperation between the CIA and the FBI since 9/11. Congress passed the PATRIOT Act that, among many other things, allowed grand jury information to be shared with the intelligence community. ${ }^{14}$ And the Foreign Intelligence Surveillance Court of Review, through a rare opinion from the special appellate

12 For commentary that Moussaoui was wrongly decided, see Brian McEvoy, Classified Evidence and the Confrontation Clause: Correcting a Misapplication of the Classified Information Procedures Act, 23 B.U. INT'L L.J. 395, 423 (2005) (characterizing Moussaoui as a "failure" and "dangerous precedent"); A. John Radsan, The Moussaoui Case: The Mess from Minnesota, 31 WM. MITCHELL L. REV. 1417, 1420, 1453 (2005) (characterizing the Moussaoui trial as a "circus" and "a sad relic of the past, a modern version of Bleak House"); Carl Tobias, Punishment and the War on Terrorism, 6 U. PA. J. CONST. L. 1116, 1125 (2004) (arguing that the Moussaoui prosecution in federal court realized little success); John Yoo, Courts at War, 91 CORNELL L. REV. 573, 599 (2006) (using Moussaoui as an example of judicial activity in national security being slow in implementation and self-correction).

13 Cf. NAT'L COMM'N ON TERRORIST ATtACKS UPON THE U.S., THE 9/11 COMMISSION REPORT 417 (2004) [hereinafter THE 9/11 COMMISSION REPORT]. According to the 9/11 Commission Report:

Each intelligence agency has its own security practices, outgrowths of the Cold War....

But the security concerns need to be weighed against the costs. Current security requirements nurture overclassification and excessive compartmentation of information among agencies. Each agency's incentive structure opposes sharing, with risks (criminal, civil, and internal administrative sanctions) but few rewards for sharing information.

Id.

14 Uniting and Strengthening America by Providing Appropriate Tools Required to Intercept and Obstruct Terrorism (USA PATRIOT) Act of 2001, Pub. L. No. 107-56, 115 Stat. 272 (codified as amended in scattered sections of $8,15,18,22,31,42,49$, and 50 U.S.C.). 
court, lowered the wall that stood in the way of exchanging personnel and information between intelligence and law enforcement. ${ }^{15}$ That lowering of the wall makes CIPA increasingly important for terrorism cases in civilian court; the FBI and the Justice Department cannot pretend that the law seals off the intelligence community from their criminal investigations. Yet Congress and the appellate courts have largely ignored CIPA since 9/11.16 While more classified information is subject to discovery and use at trial, the scholarship about CIPA lags behind.

\section{B. CIPA Is Not Magic}

The Bush Administration emphasized prevention over prosecution of terrorism cases. As counterterrorism went to the dark side, they kept regular courts away from the action. They opted for extraordinary renditions, black sites, enhanced interrogations, and military commissions. Those who once criticized Bush-particularly Democrats-now encourage the Obama Administration to return terrorism cases to criminal justice. ${ }^{17}$ For them, KSM's designation for trial in federal district court was a step in the right direction, a clear statement for the rule of law. These critics should recognize, however, that the executive's tendency to classify too much information is not the source of all problems in handling terrorism in civilian court. And they should take as given that cooperation between intelligence and law enforcement plays a critical role in keeping the nation safe. ${ }^{18}$

On behalf of Human Rights First, two former federal prosecutors prepared a long report concluding that criminal justice can handle terrorism cases. ${ }^{19}$ But their study, no matter how much they posture for civil libertarians, is of limited value in figuring out what to do with KSM and other suspected high-level terrorists. First, as to the period after $9 / 11$, their study examined only minor cases of material support to

15 In re Sealed Case, 310 F.3d 717 (FISA Ct. Rev. 2002).

1618 U.S.C. app. $3 \S \S 1-6(2006)$ (corresponds to Classified Information Procedures Act, Pub. L. No. 96-456, §§ 1-6, 94 Stat. 2025 (1980)).

17 See, e.g., Dan Eggen, Reno Joins Criticism of Anti-Terror Strategy; Former Prosecutors Urge Court to Act Against Indefinite Detention of Suspects, WASH. POST, Nov. 22, 2006, at A6 (describing a brief filed by former Attorney General Janet Reno and seven other former Justice Department officials criticizing the Bush Administration for trying terrorism suspects outside the criminal justice system).

18 Cf. THE 9/1 1 COMMISSION REPORT, supra note 13, at 417 (recommending that intelligence "[i]nformation procedures should provide incentives for sharing, to restore a better balance between security and shared knowledge" (emphasis added)).

19 RICHARD B. ZABEL \& JAMES J. BENJAMIN, JR., HUMAN RIGHTS FIRST, IN PURSUIT OF JUSTICE: PROSECUTING TERRORISM CASES IN THE FEDERAL COURTS (2008), available at http://www.humanrightsfirst.info/pdf/080521-USLS-pursuit-justice.pdf. 
terrorism. The Bush Administration, in part to avoid problems under CIPA, turned away from the federal courts and dealt with high-level cases through alternative means. Second, in a significant error, the two authors failed to interview intelligence officers to learn the true costs of public trials to sources and methods. Accordingly, their study does not address what is necessary to surmount the obstacles that compelled the Bush Administration to move away from civilian courts after $9 / 11$. For the two former prosecutors, CIPA is a wand to wave at all problems of mixing classified information with public trials. But CIPA, as shown below, is not really a magic wand.

For the reality of a new century, American justice must reconcile secrecy and due process. The Obama Administration, beyond the simple rhetoric of hope and change, must deal with the complexities of terrorism cases. KSM is just one of their challenges. Going beyond KSM's case, this Article asks and answers three generic questions. First, to what extent should "alignment" cause intelligence agencies to fall within a prosecutor's duty to search for discoverable information in terrorism cases? In the last century, a CIA lawyer named Jonathan Fredman provided one answer. ${ }^{20}$ Here, in light of $9 / 11$, I draw on my own experiences in the CIA and the Justice Department to place reasonable limits on alignment. Second, should a court consider the sensitivity of information in deciding whether (and in what form) a defendant can use it at trial? The answer to this question has resulted in a split among federal circuits. After reviewing the details of the split, I suggest that Congress should impose uniformity on CIPA practice by amending $\S 6$ of CIPA to make explicit an affirmative answer to this question. Third, to protect classified information further, should Congress allow portions of a trial to be closed to all but the judge, jury and the parties rather than rely on substitutions and summaries of sensitive information? My answer, as explained below, is yes.

CIPA, designed many years ago for espionage cases, has become archaic. As soon as possible, CIPA should be amended to deal more effectively with terrorism cases. Unlike defendants in espionage cases, the defendants in terrorism cases never had access to top-secret information. Take Moussaoui and KSM as basic examples. The potential benefits of increased cooperation between intelligence and law enforcement should not be squandered through antiquated notions of what information must be turned over to these defendants and the courts.

CIPA and related practices have tilted too much in favor of defendants since the statute was enacted. Besides amending CIPA to tilt it back toward the intelligence community, Congress should

20 Jonathan M. Fredman, Intelligence Agencies, Law Enforcement, and the Prosecution Team, 16 YALE L. \& POL'Y REV. 331 (1998). 
empower trial courts to expand their use of "silent witnesses" and to adopt other practices to protect classified information. Under an amended version of CIPA and with new practices, intelligence officers can be protected by closed portions of a trial, a vetting of the jury venire, silent witness practice, disguises and pseudonyms, and many other techniques. Any tilt toward the intelligence community, to be sure, does affect the criminal defendant's right to obtain discovery and to present full evidence at a public trial. Yet, if CIPA functions well, every once in a while national security must prevail over a defendant's rights.

In answering the three questions, I try to be open about my firsthand experience with CIPA - and about my biases. During my tenure at the CIA, while I held a top-secret clearance, I represented the Agency's interests on several cases involving classified information in the courts. Now that I am independent of the CIA, this academic commentary takes that representation to another level. To help answer the questions about alignment, substitutions, and closed trials, I provide background in the following section on the prosecutor's duty to disclose and on CIPA's mechanics. Next, I answer the three questions one at a time.

\section{BACKGROUND}

\section{A. The Prosecutor's Duty to Disclose}

A federal prosecutor has constitutional and statutory duties to disclose information to defendants. The overall duty is binary: Either information needs to be turned over or not. This duty stems from four sources: Brady v. Maryland; Giglio v. United States; Rule 16 of the Federal Rules of Criminal Procedure; and the Jencks Act. These cases and rules, like CIPA, were on the books before a new consensus emerged that American prosecutors and spymasters should cooperate more against international terrorism. The rules-at least in their current form - do not contain any exceptions for classified information. CIPA, by the same token, only goes so far in resolving the problems of including the intelligence community in the prosecutor's duty to disclose information to criminal defendants. Congress, after all, did not purport to change the rules of evidence in cases involving classified information. ${ }^{21}$

21 S. REP. NO. 96-823, at 2 (1980), reprinted in 1980 U.S.C.C.A.N. 4294, 4295 [hereinafter SENATE REPORT]. 
Brady v. Maryland ${ }^{22}$ sets forth the constitutional basis for the prosecutor's duty to disclose exculpatory information. In Brady, the defendant admitted to participating in the charged crime but claimed his accomplice did the actual killing. ${ }^{23}$ Before trial, the defense asked the prosecution to disclose the accomplice's extrajudicial statements. ${ }^{24}$ Although the prosecutor disclosed some statements, he withheld the accomplice's confession to the killing. ${ }^{25}$ This failure to disclose, the court ruled, violated the defendant's due process. ${ }^{26}$

Giglio v. United States ${ }^{27}$ expanded Brady by making documents within the prosecutor's entire office, even those concerning an unrelated case, subject to discovery. ${ }^{28}$ In Giglio, the government failed to disclose a promise of immunity to its key witness because the prosecutor working the case was unaware of this promise. ${ }^{29}$ On review, the Court held that the government still had a duty to disclose this information because it was within the other prosecutor's scope of authority and was therefore attributable to the government. ${ }^{30}$ In the end, the prosecutor's office is a team, not a collection of separate players. ${ }^{31}$

Based on the Court's refusal to limit a prosecutor's inquiry to only those facts the prosecutor himself knows, an important question is how far the inquiry extends in terrorism cases. It may be appropriate to impute information in an FBI file to the prosecutor when investigators and prosecutors have established a close working relationship. But should information at the CIA or the National Security Agency always be imputed to a federal prosecutor? The intelligence function differs from the criminal justice function, and the prosecutor, working from a

22373 U.S. 83 (1963).

23 Id. at 84 .

24 Id.

25 Id.

26 Id. at 86. The Supreme Court later clarified its holding in Brady. To amount to a constitutional violation, the failure to disclose must deprive the defendant of a fair trial; a conviction will only be overturned if the failure undermines confidence in the trial's outcome. United States v. Bagley, 473 U.S. 667, 678 (1985); see also United States v. Agurs, 427 U.S. 97, 109-10 (1976) ("The mere possibility that an item of undisclosed information might have helped the defense, or might have affected the outcome of the trial, does not establish 'materiality' in the constitutional sense.").

27405 U.S. 150 (1972).

28 Id. at 154; see also Fredman, supra note 20, at 349.

29 Giglio, 405 U.S. at 152-53.

30 See id. at 154 ("A promise made by one attorney must be attributed, for these purposes, to the Government."); see also United States v. Meros, 866 F.2d 1304, 1309 (11th Cir. 1989); United States v. Antone, 603 F.2d 566, 567-70 (5th Cir. 1979). Whether an investigating agent is considered a member of the "prosecution team" is analyzed on a case-by-case basis. R. Michael Cassidy, "Soft Words of Hope:" Giglio, Accomplice Witnesses, and the Problem of Implied Inducements, 98 NW. U. L. REV. $1129,1150 \mathrm{n} .112$ (2004) (citing Meros, 866 F.2d at 1309).

31 Giglio, 405 U.S. at 154; see Jason B. Binimow, Annotation, Constitutional Duty of Federal Prosecutor to Disclose Brady Evidence Favorable to Accused, 158 A.L.R. FED. 401, §2(a) (1999). 
different site, might not be able to make it past the security checkpoints at the CIA or NSA. In short, both Brady and Giglio leave undefined the outer limits of a prosecutor's duty. ${ }^{32}$ This imprecision creates many complications for terrorism cases in civilian court.

Rule 16 of the Federal Rules of Criminal Procedure, which defines the mutual obligations of the defendant and the government, adds to the ambiguity. In practice, most of the information regulated by Rule 16 flows from the government to the defendant. The government must provide defendants with: (1) their prior oral statements; (2) written statements made by the defendant that are within the government's possession, custody, or control; (3) written records containing the substance of statements made by the defendant; and (4) the defendant's testimony before a grand jury. ${ }^{33}$ The government must do all this before trial. Therefore, Rule 16 does not allow the intelligence community to hold on to files until and unless they are needed at trial. Since Rule 16's plain language uses the term "government" rather than "prosecutor," a significant CIPA issue is whether the discovery obligations extend to the intelligence community. In many cases, the relevant unit of "government" is tied to a core of prosecutors and investigators. Nonetheless, the Rule does not address the specifics of alignment: Does the prosecutor in the Southern District of New York, for example, need to produce defendant statements that NSA intercepted in a completely unrelated operation? ${ }^{34}$

The Jencks Act, meanwhile, is the exclusive means by which a defendant may request prior statements of government witnesses. It suffers from a defect similar to Rule 16 , however. It imposes discovery obligations on the "United States" generally, not tethered to any one governmental entity. 35 The Act requires information to be turned over to the defendant if: (1) there has been a witness statement; (2) the United States possesses the statement; and (3) the statement relates to the witness's testimony at trial. ${ }^{36}$ Given that intelligence officers and

32 See infra Part III.

33 FED. R. CRIM. P. 16(a)(1).

34 Rule 16 contains a carve-out akin to an attorney work-product protection for internal documents related to the government's investigation of the case. Id. 16(a)(2). The rule also subjects discovery of government witnesses to the Jencks Act. Id. Neither exception addresses the issue of alignment.

3518 U.S.C. $\$ 3500$ (2006); United States v. Covello, 410 F.2d 536, 543 (2d Cir. 1969); see also Goldberg v. United States, 425 U.S. 94, 103 (1976). The Jencks Act was Congress's response to Jencks v. United States, 353 U.S. 657 (1957). In Jencks, the Court held that Jencks was entitled to inspect reports that related to the trial testimony of two government witnesses. Id. at 668-69. Justice Clark, in dissent, said the Court's new rule was "foreign to [the United States'] federal jurisprudence"; intelligence agencies that assist on law enforcement "may as well close up shop, for the Court has opened their files to the criminal and thus afforded him a Roman holiday for rummaging through confidential information as well as vital national secrets." Id. at 680-82 (Clark, J., dissenting). Justice Clark thus foresaw the CIPA problem of alignment.

3618 U.S.C. $\$ 3500($ b) 
their human sources work for the United States government, the statute's loose language could be read to impose an obligation on the "United States" to disclose even the identities of CIA human sources with the most tangential connections to criminal cases.

Together, Brady, Giglio, Rule 16, and the Jencks Act place a burden and a responsibility on the prosecutor that may reach into several agencies at once. For the espionage and terrorism prosecutor, discovery creates more than the usual headaches. The prosecutor is probably more comfortable with searches in the Justice Department, which, technically speaking, includes colleagues in the FBI. The searches become more complicated in the intelligence community because much, if not all, of the discoverable material will be classified. There the prosecutor confronts a culture of pervasive secrecy.

Classification makes it even more difficult for the prosecutor to oversee the search. At a minimum, all prosecutors and investigators on the case will need security clearances. For the prosecutors to be able to review everything, those top-secret clearances will need to be passed from security officers at the Justice Department to security officers at the intelligence agency. Once a prosecutor and an intelligence agency become aligned on a terrorism case, discovery can be a nightmare for both.

\section{B. A Response to Espionage Cases}

The drafting of CIPA was influenced by the concept of "graymail." 37 Graymail occurs when a defendant possesses classified information and threatens to reveal this information if he is brought to trial. Thus, in deciding whether to prosecute a traitor, the government is frequently in a bind: A public trial could lead to the disclosure of the very secrets that required protection in the first place. ${ }^{38}$ This creates the "disclose-or-dismiss" dilemma. ${ }^{39}$ If the cost of prosecution would outweigh the potential benefit of a guilty verdict, an intelligence agency may advise the prosecutor to dismiss the case before it goes to trial. In the words of Philip B. Heymann, a Harvard professor who served at senior levels in the Justice Department, the government's problems would then go "beyond the failure to redress particular instances of illegal conduct." 40 As Heymann notes, foregoing prosecution "foster[s]

37 See SENATE REPORT, supra note 21, at 2, reprinted in 1980 U.S.C.C.A.N. at 4295.

38 Id.

39 See id. at 3, reprinted in 1980 U.S.C.C.A.N. at 4297.

40 Graymail Legislation: Hearings on H.R. 4736 Before the Subcomm. on Legislation of the Permanent Select Comm. on Intelligence, 96th Cong., 1st Sess. 5 (1979) [hereinafter Graymail Hearings] (statement of Philip B. Heymann). 
the perception that government officials and private persons with access to military or technological secrets have a broad de facto immunity from prosecution for a variety of crimes." 41 And the perception that spies are beyond the law undermines confidence in the criminal justice system.

A defendant's motives for graymail are not always the same:

Sometimes graymail is actively employed by an unscrupulous defendant who threatens to publicly reveal all kinds of sensitive information, even if it has no possible bearing on the issues of the case .... At other times the defendant seeks only to exercise his right to present to the jury admissible evidence that is relevant to a legitimate defense theory and which consists of classified information. ${ }^{42}$

Regardless of the defendant's motives, sometimes secrets are compromised for a wrongdoer to be punished. That is accepted. To enforce laws designed to protect national security, however, the government should not have to suffer too much harm. ${ }^{43}$ A balance is necessary for this range of cases from espionage to terrorism.

To reduce graymail's efficacy, Congress enacted CIPA in $1980 . .^{44}$ In the codebooks, CIPA takes no more than ten pages. CIPA was designed for espionage cases, not terrorism cases. CIPA, however, does not prevent the discovery or use of classified information in criminal cases. ${ }^{45}$ Rather, it is a procedural statute that allows the government, before the court impanels a jury, to make an informed decision about the effects a particular prosecution will have on national security. ${ }^{46}$ Before CIPA, a prosecutor could only guess what classified information the accused spy might seek to disclose, whether the court would ultimately rule it admissible, and whether it would be leaked-all before admissibility was determined during the course of a public trial. ${ }^{47}$

41 Id.

42 Id. at 1 (testimony of Hon. Morgan Murphy); see also SENATE REPORT, supra note 21, at 3, reprinted in 1980 U.S.C.C.A.N. at $4296-97$ ("It would be a mistake, however, to view the 'graymail' problem as limited to instances of unscrupulous or questionable conduct by defendants since wholly proper defense attempts to obtain or disclose classified information may present the government with the same 'disclose or dismiss' dilemma.").

43 SENATE REPORT, supra note 21, at 2, reprinted in 1980 U.S.C.C.A.N. at 4295 ("The government often must choose between disclosing classified information in the prosecution or letting the conduct go unpunished. In the words of one Justice Department Officials [sic] who testified before the subcommittee, "To what extent must we harm the national security in order to protect the national security?'").

44 Timothy J. Shea, CIPA Under Siege: The Use and Abuse of Classified Information in Criminal Trials, 27 AM. CRIM. L. REV. 657, 661 (1990).

45 United States v. Mejia, 448 F.3d 436, 455 (D.C. Cir. 2006); see also United States v. Moussaoui, 65 F. App'x 881, 887 (4th Cir. 2003) ("CIPA alone cannot justify the sealing of oral argument and pleadings."); United States v. Yunis, 867 F.2d 617, 621-22 (D.C. Cir. 1989) ("[CIPA] creates no new rights of or limits on discovery . ...").

46 SENATE REPORT, supra note 21 , at 1, reprinted in 1980 U.S.C.C.A.N. at 4294-95.

47 Id. at 4, reprinted in 1980 U.S.C.C.A.N. at 4297; see also Richard P. Salgado, Government Secrets, Fair Trials, and the Classified Information Procedures Act, 98 YALE L.J. 427, 431-32 
Sometimes, despite the prosecutor's best guesses, trials were delayed in midstream while complications were sorted out outside the jury's presence. CIPA changed all that by requiring defendants to notify the government of any classified information the defendant "reasonably expects to disclose... in any manner in connection with any trial or pretrial proceeding." 48

The statute, nonetheless, is silent on the precise contours of the defendant's notice under $\S 5.4^{49}$ Defendants are not required to explain the relevance of particular documents, ${ }^{50}$ but the notice must be sufficiently detailed so the government can determine the extent to which the use of the evidence at trial might threaten national security. ${ }^{51}$ A defendant's failure to comply with $\S 5$ may preclude the use of the non-described classified information at trial and may prohibit the defendant's examination of any witness about that information..$^{52}$

The government may move, at any time, for a protective order under $\S 3$ of CIPA. Section 3 allows the court to "issue an order to protect against the disclosure of any classified information disclosed by the United States to any defendant in any criminal case in a district court of the United States." 53 If the government makes a specific showing of harm to national security, ${ }^{54}$ the court is likely to grant a protective order, triggering other conditions on the disclosure and use of classified information. ${ }^{55}$ Protective orders are quite common in terrorism cases.

(1988). Congress also acknowledged that the government may need to disclose secrets in its case in chief, increasing the chance the defendant may need classified information. $C f$. SENATE REPORT, supra note 21, at 4, reprinted in 1980 U.S.C.C.A.N. at 4297 ("The situation is further complicated in cases where the government expects to disclose some classified items in presenting its case.").

4818 U.S.C. app. $3 \S 5$ (2006).

49 Id. ("Such notice shall include a brief description of the classified information [the defendant reasonably expects to disclose at any trial or pretrial proceeding].").

50 Saul M. Pilchen \& Benjamin B. Klubes, Using the Classified Information Procedures Act in Criminal Cases: A Primer for Defense Counsel, 31 AM. CRIM. L. REV. 191, 201-03 (1994).

51 United States v. Rewald, 889 F.2d 836, 855 (9th Cir. 1989), amended on other grounds, 902 F.2d 18 (9th Cir. 1990); see, e.g., United States v. Zettl, 835 F.2d 1059 (4th Cir. 1987) (concluding defendants' listing of hundreds of documents they proposed to introduce, rather than parts thereof, was not fatally defective; any error was cured by the detailed manner in which the district court conducted hearings to determine use, relevance, or admissibility of that information).

5218 U.S.C. app. $3 \S 5$.

53 Id. $\S 3$; see, e.g., United States v. Poindexter, No. 88-0080, 1988 WL 148597 (D.D.C. Apr. $15,1988)$ (providing an example of a protective order entered in an Iran-Contra case).

54 See United States v. Rosen, 487 F. Supp. 2d 703, 716-17 (E.D. Va. 2007) (citing PressEnter. Co. v. Super. Ct., 464 U.S. 501, 510 (1984); In re Wash. Post Co., 807 F.2d 383, 391-92 (4th Cir. 1986)).

55 Pilchen \& Klubes, supra note 50, at 197; see, e.g., United States v. Poindexter, 727 F. Supp. 1470, 1472, 1486 (D.D.C. 1989) (approving a procedure in which the defendant identified documents he wanted to share with witnesses for use at trial, an interagency group of government security officers performed a full classification review of those documents, but the group did not 
Under $\S 6$, the government may also request a pretrial hearing to "make all determinations concerning the use, relevance, or admissibility of classified information that would otherwise be made during the trial or pretrial proceeding." 56 Both parties may be present, but the hearing is held in camera if the Attorney General certifies, as often occurs, that a public proceeding may result in the disclosure of classified information.57 In Moussaoui, for example, the $\S 6$ hearings were closed, and the defense lawyers with security clearances participated while Moussaoui was excluded.

Despite all the changes CIPA brought about for classified information involved in trials, Congress did not tinker with the rules of evidence. The Senate Judiciary Committee emphasized that a "defendant should not be denied the use of information that he would otherwise use simply because of the procedures of [CIPA]."58 The standard for admissibility was to remain the same, "regardless of the sensitivity of the information." 59

Now, a particular concern in terrorism cases is that a defendant who did not previously possess classified information might acquire it through discovery. ${ }^{60}$ The prosecution, on its own, may provide the defendant with discovery, or the prosecution may provide discovery after the court has conducted an in camera, ex parte review of the arguably discoverable information. ${ }^{61}$ However the discovery is provided, the government may ask the court under $\S 4$ to permit substitutions, admissions, or summaries of the classified information. ${ }^{62}$ Prosecutors use their discretion on close calls. It is their reputationsand their licenses-that are on the line. Whether intelligence agencies approve or not, some prosecutors are lenient with discovery under $\S 4$. They try to convince intelligence agencies that the court will later reward this leniency by limiting the use of the information under $\S 6$ at

disclose to the prosecutors which documents were reviewed). One certain condition in the protective order is for the defense to review and discuss classified information at a guarded "Secure Compartmented Information Facility" (SCIF) maintained by the Department of Justice. Pilchen \& Klubes, supra note 50, at 197.

56 See 18 U.S.C. app. $3 \S 6($ a).

57 Id.; see also id. \$ 6(c)(1) ("The court shall hold a hearing on any motion under this section. Any such hearing shall be held in camera at the request of the Attorney General.").

58 SENATE REPORT, supra note 21 , at 8 , reprinted in 1980 U.S.C.C.A.N. at 4301.

$59 \mathrm{Id}$; see also H.R. REP. No. 96-1436, at 12 (1980) (Conf. Rep.), reprinted in 1980 U.S.C.C.A.N. 4307, 4310 [hereinafter HOUSE REPORT] ("[T]he conferees agree that ... nothing ... is intended to change the existing standards for determining relevance and admissibility.").

6018 U.S.C. app. $3 \S 4$ ("The court, upon a sufficient showing, may authorize the United States to delete specified items of classified information from documents to be made available to the defendant through discovery under the Federal Rules of Criminal Procedure.").

61 The standard for determining if classified information is relevant and thus discoverable depends on jurisdiction. See infra note 182.

6218 U.S.C. app. $3 \S 6(c)(1)$. 
trial. Other prosecutors, seeking to limit expectations from the beginning, are restrictive under $\S 4$. A prosecutor does not have a choice, of course, when an "insider" defendant (say, a former American government official) already possesses the classified information. But these choices do apply to "outsider" cases, including suspected terrorists.

A common method of substitution is to redact classified information from a document. ${ }^{63}$ Further, the government may propose to lift unclassified portions onto a new document for the defendant's use in discovery - or at trial. Whatever the form of substitution, the court will grant the government's motion for substitution at trial as long as the defendant has "substantially the same ability" to make a defense as was provided by the classified information described in the defendant's notice. ${ }^{64}$

If the court rejects the government's proposal for substitution under $\S 6(\mathrm{c})$ and the Attorney General files an affidavit objecting to disclosure, the court must order the defendant (who already possesses the classified information on his own or through discovery) not to disclose it. ${ }^{65}$ CIPA, respecting separation of powers, recognizes that the judiciary cannot impose declassification and disclosure on the executive. The executive's refusal to disclose does, however, carry consequences. The court will dismiss the charges unless it determines that the interests of justice demand a lesser sanction such as the dismissal of specified counts of the indictment, a finding against the

63 Upon a sufficient showing, the United States may "delete specified items of classified information from documents to be made available to the defendant through discovery under the Federal Rules of Criminal Procedure, to substitute a summary of the information for such classified documents, or to substitute a statement admitting relevant facts that the classified information would tend to prove." 18 U.S.C. app. $3 \S 4$.

64 Id.; see also United States v. Juan, 776 F.2d 256, 258 (11th Cir. 1985) ("Such a motion should be granted if the alternative "will provide the defendant with substantially the same ability to make his defense."); see, e.g., United States v. Rezaq, 134 F.3d 1121 (D.C. Cir. 1998) (permitting bare statements of fact in lieu of classified documents in prosecution for aircraft piracy); United States v. Libby, 467 F. Supp. 2d 20 (D.D.C. 2006) (concluding government's proposed substitutions were sufficient to provide defendant, a former government official charged with providing false statements to the FBI and false testimony to grand jury investigating leak of a covert CIA analyst's identity, with substantially the same ability to make his defense). In United States v. Clegg, the Ninth Circuit denied the government's motion to substitute because the proposed substitution would decrease the reasonableness of the defendant's belief that the government approved his activities in exporting firearms. 846 F.2d 1221, 1224 (9th Cir. 1988).

6518 U.S.C. app. $3 \S 6(\mathrm{e})(1)$; Pilchen \& Klubes, supra note 50, at 207 n.74 ("CIPA does not comprehend judicial re-examination of the status of classified information, or review of the Attorney General's decision to block disclosure. The legislative history recognizes that 'classification is an executive, not a judicial function.'" (citing SENATE REPORT, supra note 21, at 10-11, reprinted in 1980 U.S.C.C.A.N. at 4304)). 
United States on any issue to which the excluded classified information relates, or the preclusion of all or part of a witness's testimony. ${ }^{66}$

If the government loses a $\S 6$ battle on substitutions or sanctions, $\S 7$ allows for interlocutory appeal. ${ }^{67}$ The appellate court assesses the trial court's ruling and examines the underlying relevance of the classified information under an abuse-of-discretion standard. ${ }^{68}$ CIPA requires the appellate court to work on an expedited basis. ${ }^{69}$ This may be difficult, especially in circuits with limited CIPA practice, when judicial clerks must obtain security clearances and courts must find secure facilities for the classified information. No matter the difficulties, an appeal under CIPA can go all the way to the Supreme Court. Even so, the Supreme Court has not involved itself in CIPA disputes, and this level of appellate review is more important in theory than in practice.

In sum, CIPA provides only a partial solution to the dilemma created "when a defendant claims that he must use classified information in defending himself." 70 It enables the government to make an earlier, more informed decision on disclosing or dismissing, but the government still has to make a decision. ${ }^{71}$ CIPA may help solve the dilemma if a court allows substitutions or summaries instead of disclosure. But if a court rejects the government's substitution or if an approved substitution does not do enough to protect sensitive information, the government must decide between prosecuting with some disclosure and dismissing the case to avoid any more disclosure.

CIPA, as noted, is aimed at those defendants who were once entrusted with secrets and later faced prosecution for abusing that trust. Examples include United States $v$. North, ${ }^{72}$ United States $v$. Poindexter, ${ }^{73}$ United States v. Smith, ${ }^{74}$ United States v. Fernandez, ${ }^{75}$

6618 U.S.C. app. $3 \S 6(\mathrm{e})(2)(\mathrm{A})$-(C). CIPA states other sanctions may be used besides the three it enumerates. Id. $\S 6(\mathrm{e})(2)$.

67 Id. $\$ \S 6(\mathrm{e})(2), 7$.

68 United States v. Fernandez, 913 F.2d 148, 154-55 (4th Cir. 1990) (citing United States v. Anderson, 872 F.2d 1508, 1515, 1518 (11th Cir. 1989); United States v. Clegg, 846 F.2d 1221, 1224 (9th Cir. 1988)).

6918 U.S.C. app. $3 \S 7(\mathrm{~b})$.

70 Graymail Hearings, supra note 40, at 1 (testimony of Hon. Morgan Murphy).

71 See SENATE REPORT, supra note 21 , at 1, reprinted in 1980 U.S.C.C.A.N. at 4294 . The Senate described CIPA's purpose as "provid[ing] pretrial procedures that will permit the trial judge to rule on questions of admissibility involving classified information before introduction of evidence in open court. This procedure will permit the government to ascertain the potential damage to national security of proceeding with a given prosecution before trial." Id.

72708 F. Supp. 389 (D.D.C. 1988).

73725 F. Supp. 13 (D.D.C. 1989).

74780 F.2d 1102 (4th Cir. 1985) (en banc).

75913 F.2d 148 (4th Cir. 1990). 
and, more recently, United States $v$. Libby. $^{76}$ But defendants in terrorism cases are not likely to know state secrets. If secrets are revealed to suspected terrorists in discovery or at trial, these secrets will inevitably make their way to other terrorists. Protective orders or other instructions from the court will not take care of all problems. A defendant who plotted to fly airplanes into buildings is not easily deterred.

As courts handle more cases that involve classified information, they must do their best to ensure that the costs of revealing secrets are minimized. If the courts do not strike an appropriate balance, the intelligence community will be right to say that the government should handle terrorists outside the civilian courts. The more the government prosecutes terrorism in the federal courts, the more its intelligence sources and methods may be exposed. That potential, as CIPA is applied today, increases with deeper cooperation between agencies.

\section{Alignments Between Prosecutors ANd Spymasters}

While CIPA explains what to do when classified information is "at issue" in a case, it does not establish when intelligence agencies have worked closely enough with prosecutors for discovery obligations to extend beyond the Justice Department. The point of alignment between the agencies is crucial, however, when suspected terrorists are charged in federal court. ${ }^{77}$

\section{A. Alignment Basics}

Alignment means an intelligence agency has worked closely enough with law enforcement for Brady, Giglio, Rule 16, and the Jencks Act to apply to that agency. When alignment exists in practice, prosecutors do not rummage through an intelligence agency's vault and determine what needs to be disclosed file by file. Instead, an administrator without a law degree searches the intelligence files in response to a laundry list from the prosecutor. After the search is complete, the prosecutor, whose case-and license-are on the line, will travel to the intelligence agency and apply the rules of discovery to decide which of the found files, if any, need to be turned over to the defense. Lawyers from the intelligence agency might intervene in the

76429 F. Supp. $2 d 18$ (D.D.C. 2006), amended on reconsideration, 429 F. Supp. 2d 46 (D.D.C. 2006).

77 See supra Part I. 
review of files to urge the prosecutor to err toward non-disclosure and substitution. After the back and forth between spymasters and prosecutors, the courts are the ultimate arbiters of what must be disclosed.

The U.S. Attorneys' Manual describes alignment as one of active involvement by an agency in the investigation or prosecution. ${ }^{78}$ Most often, prosecutors should not become entangled with intelligence files unless the facts of the case suggest an affirmative duty to do so. ${ }^{79}$ The Manual, echoing back to the historical division between law enforcement and intelligence, is cautious:

Although coordination on matters of common concern is critical to the proper functioning of the two communities, prosecutors must be aware of the concomitant need of both communities to maintain a well-delineated separation between criminal prosecutions and foreign intelligence activities, in which less-stringent restraints apply to the government. ${ }^{80}$

The Manual acknowledges the inevitable liaisons between intelligence and law enforcement. More to the point, the Manual suggests an obligation to search intelligence agency files "based not upon a known duty to the defendant or to a known nexus to national security matters but rather on the fact that the case meets a certain profile of cases likely to implicate such issues." 81 This profile includes terrorism cases. ${ }^{82}$ All other things being equal, the more tailored the defendant's request, explaining why pertinent files may be in the intelligence community, the more likely the prosecutor must search.

Of all the discovery rules, Brady is probably the most difficult for the aligned team to navigate because of its constitutional underpinnings. To exclude the intelligence community from Rule 16, prosecutors can cite cases in which probation officers are considered outside the "government" for purposes of the rule. ${ }^{83}$ Similarly, to exclude the intelligence community from Jencks obligations, prosecutors can look

78 U.S. DEP'T OF JUSTICE, UNITEd States ATtORneys' Manual tit. 9, CRiminal RESOURCE MANUAL $\$ 2052$ (B)(1) (2006) [hereinafter U.S. ATTORNEYS' MANUAL]. According to the U.S. Attorneys' Manual:

When an [intelligence community] component has actively participated in a criminal investigation or prosecution-that is, has served in a capacity that exceeds the role of providing mere tips or leads based on information generated independently of the criminal case-it likely has aligned itself with the prosecution and its files are subject to the same search as would those of an investigative law enforcement agency assigned to the case.

Id.

79 Id. $\S 2052(\mathrm{~B})(2)(\mathrm{a})$.

80 Id. $\S 90.210(\mathrm{~A})$.

81 Id. $\S 2052(\mathrm{~B})(4)$.

82 Id.

83 See, e.g., United States v. Zavala, 839 F.2d 523, 528 (9th Cir. 1988) (concluding Brady does not extend to reports held by the court or the probation office). 
for cases in which the Bureau of Prisons falls outside the scope of that rule. Brady is thornier.

\title{
B. The Circuit Split Concerning Alignment
}

\begin{abstract}
Although the Supreme Court has not opined on alignment, the federal circuits have been active in delineating a prosecutor's obligations under Brady and other discovery rules. ${ }^{84}$ Even so, these cases tend to relate to agencies other than the CIA. Their usefulness for our purposes depends on the strength of their analogy to the intelligence community. ${ }^{85}$
\end{abstract}

84 See, e.g., United States v. Pelullo, 399 F.3d 197, 216-18 (3d Cir. 2005) (holding Brady did not require disclosure of documents collected by Pension and Welfare Benefits Administration (PWBA) because PWBA was not part of the team that prosecuted defendant for embezzlement of employee pension funds, money laundering, and conspiracy); United States v. Casas, 356 F.3d 104,116 (1st Cir. 2004) (holding prosecution had no obligation to produce citizenship application containing witness's perjury since the document was not in the prosecution's files, but at another agency not under its supervision); United States v. Velte, 331 F.3d 673, 680 (9th Cir. 2003) (holding that, because a weather station was not acting for government in collecting humidity data, prosecutor not required to disclose this data to a defendant charged with willfully setting fire to federal land); Moon v. Head, 285 F.3d 1301, 1309-10 (11th Cir. 2002) (holding Tennessee investigator who testified on behalf of prosecution during sentencing phase of capital murder case did not become part of Georgia prosecutor's team, such that Brady material in investigator's hands had to be disclosed to defendant, when Tennessee law enforcement officers and Georgia prosecutors had not shared resources); United States v. Beers, 189 F.3d 1297, 1304 (10th Cir. 1999) (holding state's knowledge and possession of potential impeachment evidence could not be imputed to federal prosecutor for purposes of establishing Brady violation, especially when the evidence resulted from an unrelated state investigation); United States v. Morris, 80 F.3d 1151, 1169-70 (7th Cir. 1996) (holding Brady did not require prosecutors to discover allegedly exculpatory information at the Office of Thrift Supervision, SEC, or IRS because none of those agencies investigated the case or participated in its prosecution); United States v. Santiago, 46 F.3d 885, 894 (9th Cir. 1995) (holding U.S. Attorney's Office had access to Bureau of Prison files because Office knew files existed, had been able to obtain one inmate's file, and both the Office and the Bureau are part of DOJ); United States v. Kern, 12 F.3d 122, 126 (8th Cir. 1993) (declining to attribute knowledge of Omaha police to federal prosecutor); United States v. Brooks, 966 F.2d 1500, 1504 (D.C. Cir. 1992) (holding U.S. Attorney's obligation under Brady extended to files in the homicide and internal affairs divisions of the District of Columbia police department due to their close working relationship in the defendant's prosecution); United States v. Deutsch, 475 F.2d 55, 57 (5th Cir. 1973) (finding that information in personnel file of Post Office employee was within prosecutor's possession), overruled on other grounds by United States v. Henry, 749 F.2d 203 (5th Cir. 1984).

85 See generally Carole Gordon Rapoport, Note, Dream Team or Evidentiary Nightmare? Defining When a Government Agency Is Part of the Prosecution Team, 9 SUFFOLK J. TRIAL \& APP. ADVOC. 81, 82 n.6 (2004). For example, in United States v. McVeigh, 954 F. Supp. 1441, 1443-44 (D. Colo. 1997), the court ordered the prosecution to request and review information from the CIA, the Defense Intelligence Agency, and the National Security Agency. The court described the prosecution's Brady burden as informing "themselves about everything that is known in all of the archives and all of the data banks of all of the agencies collecting information which could assist in the construction of alternative scenarios to that which they intend to prove at trial." Id. at 1450. 
In all, the federal circuits have taken three approaches in deciding whether a governmental agency is aligned with the prosecution team: narrow, broad, and moderate. ${ }^{86}$ The Second, Fourth, and Eighth Circuits define alignment narrowly. ${ }^{87}$ According to these circuits, there is no alignment without some concrete connection between a state or federal entity and the prosecution. ${ }^{88}$ For example, in United States $v$. Locascio, ${ }^{89}$ the Second Circuit found no alignment and no Brady violation where federal prosecutors failed to disclose an exculpatory report written by FBI agents not involved in the investigation. ${ }^{90}$ Thus, the Second Circuit, which includes the Southern District of New York, might be an attractive venue for handling terrorism cases under CIPA.

In contrast, the First, Third, and Ninth Circuits define alignment broadly, taking a "monolithic view of government" and finding alignment between agencies because the government is considered a single entity. ${ }^{91}$ In United States $v$. Osorio, ${ }^{92}$ for example, the court ordered the prosecutor to turn over impeachment material about the government's chief witness in a trial for conspiracy to possess and distribute cocaine. ${ }^{93}$ The prosecutor had failed to disclose that the U.S. Attorney's Office and the FBI believed the chief witness previously distributed roughly one to two kilograms of cocaine a week, a belief which directly contradicted the witness's testimony. ${ }^{94}$ The First Circuit held that the prosecutor was "negligent" in carrying out his Giglio obligations because he apparently failed to "make reasonable inquiry of those in a position to have relevant knowledge." 95 The court observed

86 Compare Rapoport, supra note 85 , at $92-96$ (discussing the narrow, broad, and moderate approaches the federal circuits have developed to define who is a member of the prosecution team and how far the prosecution must go in its searches), with Mark D. Villaverde, Note, Structuring the Prosecutor's Duty to Search the Intelligence Community for Brady Material, 88 CORNELL L. REV. 1471, 1493-1510 (2003) (arguing for three general categories: "the "prosecution team' standard," "the availability/accessibility standard," and "the actual knowledge and possession" standard).

87 Rapoport, supra note 85 , at 92-93.

88 Id. at 92 n.75 (citing United States v. Hawkins, 78 F.3d 348, 351 (8th Cir. 1996) (refusing to hold Missouri prosecutor accountable for information Illinois prosecutor held)); see, e.g., United States v. Quinn, 445 F.2d 940, 944 (2d Cir. 1971) (declining to impute Florida state prosecutor's knowledge to Assistant U.S. Attomey).

896 F.3d 924 (2d Cir. 1993).

90 Id. at $949-50$.

91 Rapoport, supra note 85, at 92-93. The Tenth Circuit, in Smith v. Secretary of New Mexico Department of Corrections, 50 F.3d 801 (10th Cir. 1995), identified that the First and Third Circuits have "taken an expansive view and have imputed a broad range of knowledge to the prosecution." Id. at 824; see also United States v. Thornton, 1 F.3d 149, 158 (3d Cir. 1993) (finding alignment and violation of a Brady duty where prosecutors failed to "follow-up" after the DEA did not respond to an initial request to advise the prosecutors of any payments made to a witness).

92929 F.2d 753 (1st Cir. 1991).

93 Id. at 756.

94 Id. at 757.

95 Id. at 760-61. 
that "[t]he prosecution of criminal activity is a joint enterprise" and "'the government' is not a congery of independent hermetically sealed compartments." 96 The First Circuit thus requires prosecutors, in fulfilling their Giglio obligations, to seek out information possessed by other governmental agencies. As a result, the First Circuit may be one of the toughest for prosecuting terrorism cases involving classified information.

The Fifth, Seventh, Eleventh, and District of Columbia Circuits take a moderate approach in defining alignment, reviewing the degree of participation and cooperation between agencies on a case-by-case basis. ${ }^{97}$ For example, in United States v. Deutsch, ${ }^{98}$ the Fifth Circuit found alignment between the Justice Department and the Post Office Department because the government sought to call a Post Office employee as its principal witness. ${ }^{99}$ The court held that the two agencies were too "closely connected" to avoid production of the employee's personnel file. ${ }^{100}$ And in United States v. Brooks, ${ }^{101}$ the District of Columbia Circuit found alignment because of the "close working relationship between the [police department] and the U.S. Attorney for the District of Columbia."102 On the other hand, unlike the courts in Deutsch and Brooks, the Seventh Circuit in United States v. Morris ${ }^{103}$ found no alignment because none of the three agencies in question was part of the team that investigated and prosecuted the criminal charges. ${ }^{104}$ Further, the defendants were not entitled to relief under Brady because they could have obtained the information themselves through the "exercise of reasonable diligence." 105

For CIPA cases, the lack of a precise discovery standard in the federal circuits creates many complications. Working from the same facts, sometimes spymasters and prosecutors reasonably disagree on whether alignment exists on a criminal case. These disagreements reinforce other differences. The CIA does not gather and store its information in the same way that the FBI does. ${ }^{106}$ And the intelligence

\footnotetext{
96 Id. at 760 .

97 Rapoport, supra note 85, at 94.

98475 F.2d 55 (5th Cir. 1973).

99 Id. at 57.

100 Id.

101966 F.2d 1500 (D.C. Cir. 1992).

102 Id. at 1503.

10380 F.3d 1151 (7th Cir. 1996).

$104 \mathrm{Id}$. at 1170.

105 Id. The defendants knew as much about the Office of Thrift Supervision, Securities and Exchange Commission, and Internal Revenue Service investigations as the prosecution did.

106 Fredman, supra note 20, at 337-38. In highlighting the differences between the CIA and the FBI, Fredman notes:

The documentary procedures of law enforcement agencies are highly specialized, directly designed to support the investigation and prosecution of offenses; their formats and modes of employment are not readily adaptable to intelligence agencies and their
} 
community, to start, is not as concerned with chains of custody and the rules of evidence. ${ }^{107}$ Hearsay from a human source or a foreign intelligence service is often the best the intelligence community has for American policymakers. In serving an insatiable demand for tips about terrorists since $9 / 11$, the CIA is not required to prove things beyond a reasonable doubt.

\section{Fredman's Take on Alignment}

For years, Jonathan Fredman's Intelligence Agencies, Law Enforcement and the Prosecution Team has been the key piece of scholarship on alignment. ${ }^{108}$ When Fredman wrote his article, the "most destructive domestic terrorist attack in American history" 109 was the Oklahoma City bombing. ${ }^{110}$ At that time, Fredman noted an uptick in the U.S. prosecution of transnational crime. Drug traffickers and other gangsters, it seemed, were going global.

A few years before KSM and his minions carried out the $9 / 11$ plot, Fredman concluded that careful planning was needed to allow prosecutors to comply with discovery rules without unduly compromising intelligence sources and methods. ${ }^{111} \mathrm{He}$ reminded us of the statutory ban on an "internal security" function for the CIA as well as the FBI's prominence in the domestic sphere. ${ }^{112}$ The collapse of communism and an increase in international crime - including weapons proliferation, narcotics trafficking, and terrorism--had begun to blur the historical separation between the CIA and the FBI. ${ }^{113}$ Even before 9/11, the neat boundaries that kept the CIA outside the United States and the FBI inside the United States began to break down. Fredman, a knowledgeable insider from the intelligence community, said U.S.

\footnotetext{
operations. Rather, the intelligence agencies organize and maintain their records in a matter conducive to intelligence analysis and dissemination, rather than for potential use as evidence.

110 Timothy McVeigh and Terry Nichols were charged and later convicted of the attack. See United States v. McVeigh, 153 F.3d 1166 (10th Cir. 1998), cert. denied, 526 U.S. 1007 (1999); United States v. Nichols, 169 F.3d 1255 (10th Cir. 1999), cert. denied, 528 U.S. 934 (1999).

111 Fredman, supra note 20 , at 369.

112 See id. at 335; see also U.S. ATTORNEYS' MANUAL, supra note 78, at tit. 9, $\$ 90.210(\mathrm{~A})$ (describing law enforcement's main purposes to "identify, target, investigate, arrest, prosecute, and convict" those who violate federal law while the intelligence community "perform[s] intelligence activities necessary for the conduct of foreign relations and the protection of the national security, including the collection of information and the production and dissemination of intelligence").

113 See Fredman, supra note 20, at 335-36.
} 
agencies were adopting a "team" approach against international drug traffickers and other criminals. ${ }^{114}$ Over a decade ago, Fredman was among the first to recognize that increased cooperation between intelligence and law enforcement created complications. Fredman, back then, laid down some parameters:

In general, the courts have held that federal discovery obligations extend to those government agencies that are so closely "aligned" with the prosecution of a specific matter that justice requires their records be subject to the respective discovery obligations. The issue also has been cast in terms of the "prosecution team," consisting of those agencies whose activities so closely support a specific prosecution that justice requires them to be subject to the discovery obligations.... These issues arise because none of the discovery rules explicitly define the intra-governmental limits of their obligations. ${ }^{115}$

From Fredman to today, from domestic to international terrorism, the basic question remains: What sort of cooperation from an intelligence agency subjects its files to discovery in criminal cases? The rules, of course, do not provide much guidance. As Fredman stated, "neither CIPA nor any other statute specifically addresses the extent to which information in the possession of the intelligence community may be subject in the first place to the defendant's rights of discovery or the prosecution's obligation to search."116 For this reason, Fredman suggested that the question be resolved by "careful planning" and by case law. ${ }^{117}$ Given the inconsistent approaches the courts have taken, ${ }^{118}$ this Article proposes that Congress hold hearings on alignment and tackle the issue head-on by amending CIPA. While more than a decade has gone by since Fredman's article, careful planning and case law still have not done the trick.

Our constitutional structure does not provide an easy solution to the conflicting demands of due process and secrecy. Failure to disclose intelligence files to a defendant, undercutting transparency and democracy, may violate rights spelled out in Brady and other cases. ${ }^{119}$ On the other hand, disclosure in even a single case may threaten the nation's security by jeopardizing current sources of information, by deterring future sources, or by compromising secret methods of collection. ${ }^{20}$ These points stand true for all captured members of al

$114 I d$.

115 Id. at 347.

116 Id. at $338-39$.

117 See id. at 369 ("Careful planning in specific situations may permit steps to avoid casting an intelligence agency as part of the prosecution team.").

118 See supra Part II.B.

119 See supra Part II.A.

120 Fredman, supra note 20, at 338. 
Qaeda who are brought to federal court. At best, our constitutional structure calls for balance.

To find a balance on alignment between the CIA and the FBI, Fredman advocated a case-by-case approach. ${ }^{121}$ Easy cases are when the prosecutor or the defendant knows that a file subject to discovery is within the intelligence community. The prosecutor has a duty to search for that file. When the prosecutor does not know of any pertinent files, two extremes frame Fredman's analysis. At one extreme, if there is no contact between intelligence and law enforcement, no passing of personnel or information between the two, alignment does not exist. A search under these circumstances would be a fishing expedition, and the law does not require it. At the other extreme, if intelligence and law enforcement work jointly on an investigation, alignment exists and a search should be done. Moreover, some cases (Fredman mentioned the proliferation of weapons of mass destruction) have an inherent intelligence component that requires a search. ${ }^{122}$ Between the extremes, Fredman conceded that many difficult calls exist. ${ }^{123}$ As he observed, the discovery obligations imposed on the intelligence community should "neither [be] unduly circumscribed nor overly extended." 124 Again, it is a question of balance.

At times, Fredman accommodated the intelligence community. He said that a defendant's request to search intelligence files should only be honored upon a strong showing of necessity: "The significant resource demands that otherwise would be placed upon prosecutors and intelligence agencies, as well as the need to avoid unnecessary risks to intelligence sources and methods, together counsel such a course."125 At other times, Fredman accommodated law enforcement-and defendants. On one case, Fredman was not too troubled by a search through the intelligence community for files connected to the Oklahoma City bombers. ${ }^{126}$ To Fredman, this broad approach to discovery and this loose theory of alignment served an "exceptional" case. ${ }^{127}$ Maybe Fredman did not imagine - or care-that this exception would become the rule.

Fredman's analysis did not deviate much, if at all, from the Justice Department's party line about alignment. ${ }^{128}$ Fredman, although a part

121 Id. at $370-71$.

$122 \mathrm{Id}$. at 370.

$123 \mathrm{Id}$.

124 Id. at 371.

125 Id. at $370-71$.

$126 \mathrm{Id}$. at 370.

127 Id.

128 Compare id. (observing that discovery would be appropriate when there is reason to believe a particular intelligence agency may have information related to a case), with U.S. ATTORNEYS' MANUAL, supra note 78, at tit. 9, CRIMINAL RESOURCE MANUAL $§ 2052(B)(4)$ 
of the intelligence community, did not question whether alignment applied to intelligence agencies at all. Nor did he push for the most restricted definition of alignment. Instead, he took a moderate approach similar to that of the Fifth, Seventh, Eleventh, and D.C. Circuits.

Fredman tackled alignment from the pre-9/11 position. His analysis was fine for the time. But, as I learned from my CIPA practice at the CIA after 9/11, alignment is conceded more and more in practice, and intelligence files are subject to deeper and deeper searches. Looming ahead of us is the potential disaster of prosecuting al Qaeda members in federal district court. In comparison to the current terrorism cases, Timothy McVeigh-and even Zacarias Moussaouiwill stand as easy examples under CIPA. Contrary to Fredman, I would like us to do more to challenge the conventional wisdom regarding alignment.

\section{The Past, Present, and Future of Alignment}

Many people have complained about restrictions on a defendant's access to classified information in terrorism proceedings, ${ }^{129}$ but few have directly questioned Fredman's approach to alignment. In the minority, one student proposes a "cabined" approach to alignment. ${ }^{130}$ Under his proposal, the duty to discover and disclose intelligence information only arises if an intelligence agency works at the prosecutor's direction and control and only extends to material produced during this relationship. ${ }^{131}$ In addition, the defendant's request must be specific enough to indicate the nature and location of the requested information. ${ }^{132}$ Other than this alternative, commentators

(stating that obligation to search intelligence agency files depends on whether "the case meets a certain profile of cases likely to implicate such issues").

129 See Joshua L. Dratel, Sword or Shield? The Government's Selective Use of Its Declassification Authority for Tactical Advantage in Criminal Prosecutions, 5 CARDOzo PUB. L. POL'Y \& ETHICS J. 171, 188-89 (2006) (arguing that government's selective declassification of information, including withholding defendant's own conversations, amounts to an unconstitutional tactical maneuver; CIPA, FISA, and Rule 16 should be modified to ensure defendant's access to own intercepted communications); Victor Hansen \& Lawrence Friedman, The Case Against Secret Evidence, 12 Roger WILLIAMS U. L. REV. 772, 817-18 (2007) (calling for the Executive branch to give a clear articulation of purpose when restricting access in terrorism cases); Ellen C. Yaroshefsky, The Slow Erosion of the Adversary System: Article III Courts, FISA, CIPA and Ethical Dilemmas, 5 CARdozo PUB. L. POL'Y \& ETHICS J. 203, 224-25, 232 (2006) (contending that over-classification, stretched definitions of terrorism offenses, and the greater internationalization of crime and law enforcement threaten to distort the adversary system, particularly when defense counsel with security clearances are excluded from discussions about potential discovery).

130 See Villaverde, supra note 86 , at $1529-32$ (proposing a three-step approach to discovery of classified information in an intelligence agency's files).

131 Id. at 1530-31.

132 Id. at 1531-32. 
have largely deferred to Fredman. 133 After 9/11, the analysis of CIPA should resist the tendency-illustrated by Fredman-to concede alignment across the board.

Some commentators have responded at a more abstract level than Fredman to greater integration between intelligence and law enforcement. One commentator worries about potential cross-over effects on civil liberties. ${ }^{134}$ Another is somewhat optimistic about an emerging paradigm that "requires a cooperative relationship among intelligence agencies, law enforcement agencies, and prosecutors, in which there is acknowledgement from the outset that ... there may be reckoning with a judge, a jury, and a defense counsel."135 Critical or supportive, the commentary on CIPA faces a changing landscape. And that landscape requires a new theory of alignment, one that reflects increasing complications since 9/11. If nothing else, Fredman's analysis must be tested against the facts of the new century.

Today, striking a balance between secrecy and due process is more difficult — and more important. Al Qaeda cases linger on the horizon. As one article notes:

The administration's concern about revealing protected information to an accused is understandable: it is the accused who has been identified and charged with violations of the law of war and terrorist actions directed against the United States. There is a lcgitimate fear that, once the accused has access to this protected information, he could seek to use it in furtherance of his own criminal conduct as well as to aid the enemies of the United States. ${ }^{136}$

Classified information is arguably valued less in terms of its substance than on the "tactical value that attaches to the way in which the information was obtained, from which foreign counterintelligence agents might learn a great deal about the nation's intelligence-gathering capabilities." 137 In other words, the use of classified information in

133 See, e.g., Fred F. Manget, Intelligence and the Criminal Law System, 17 STAN. L. \& POL'Y REV. 415, 422 \& n.33 (2006) (noting that "[o]ther commentators have covered [the interaction between intelligence and the criminal law system] with great thoroughness" and citing Fredman); Daniel Richman, Prosecutors and Their Agents, Agents and Their Prosecutors, 103 COLuM. L. REV. 749, 817 n.308 (2003) (recommending Fredman's article "[f]or an exploration of the special problems raised by the involvement of intelligence agencies in a criminal investigation").

134 Norman C. Bay, Executive Power and the War on Terror, 83 DENV. U. L. REV. 335, 335 (2005) (expressing concern that two paradigm shifts in the war on terror, viewing terrorism as a military issue instead of a law enforcement issue and greater centralization of intelligence and law enforcement, have had an adverse effect on civil liberties).

135 Richard B. Schiff, A Counterintelligence Perspective, or How I Learned to Stop Worrying and Love the Wall, 52 FED. LAW. 32, 35-36 (2005) ("We need not look longingly backward, but rather intelligence agencies and their new best friends, prosecutors, need to understand that, at least as far as the government's responsibility for discovery is concerned, the collapse of the wall has been a mixed blessing.").

136 Hansen \& Friedman, supra note 129, at 778.

137 Id. at 789. 
terrorism cases increases the risk that intelligence sources and methods will be exposed, an exposure that undercuts national security. To be effective in protecting our country, the intelligence community must be able to honor the promises it makes to human sources and to liaison services. No one will work with the CIA, after all, if it fails to protect secrets. That said, classification should not be a means for the intelligence community to cover up embarrassments and crimes. One word Fredman and I keep coming back to is balance.

Updates to CIPA should also take into account changes in other statutes. At the time of Fredman's writing, the CIA was allowed to obtain information outside the U.S. about non-U.S. citizens on behalf of law enforcement agencies. ${ }^{138}$ Law enforcement and intelligence agencies were further fused together when the PATRIOT Act was passed. ${ }^{139}$ This statute, passed after $9 / 11$, called for "expediti[ous] disclos[ure] ... of foreign intelligence acquired by ... the Department of Justice or an element of such department or agency . . . in the course of a criminal investigation" to intelligence personnel. ${ }^{140}$ In 2004, the Intelligence Reform \& Terrorism Prevention Act (IRTPA), ${ }^{141}$ in creating the Office of the Director of National Intelligence, expanded the definition of "intelligence" to include any intelligence related to national security, without regard to the source of the information. ${ }^{142}$ IRTPA "provid[ed] and facilitat[ed] the means for sharing terrorism information among all appropriate Federal, State, local, and tribal entities, and the private sector," 143 and added incentives for information-sharing. ${ }^{144}$ IRTPA also called on the FBI to "continue efforts to improve [its] intelligence capabilities ... and to develop and maintain within the Bureau a national intelligence workforce." 145 All in all, strict compartmentalization between the CIA and the FBI was supposed to disappear. ${ }^{146}$ CIPA, passed many years before $9 / 11$, should

138 Intelligence Authorization Act for Fiscal Year 1997, Pub. L. No. 104-293, § 814, 110 Stat. 3461,3483 (1996) ("'E]lements of the intelligence community may, upon the request of a United States law enforcement agency, collect information outside the United States about individuals who are not United States persons. Such elements may collect such information notwithstanding that the law enforcement agency intends to use the information collected for purposes of a law enforcement investigation or counterintelligence investigation.").

139 See Pub. L. No. 107-56, 115 Stat. 272 (2001).

140 See id. $\$ 905,115$ Stat. at 388.

141 Pub. L. 108-458, 118 Stat. 3638 (2004)

142 Id. $\S 1012,118$ Stat. at 3662 ("The terms 'national intelligence' and 'intelligence related to national security' refer to all intelligence, regardless of the source from which derived ....").

143 Id. $\S 1016,118$ Stat. at 3664-65.

144 Id. $\S 1016,118$ Stat. at 3666.

145 Id. $\$ 2001,118$ Stat. at 3700 .

146 Manget, supra note 133, at 420 ("Every major recent review of U.S. intelligence policy and organization has called for increased information sharing, unity of command and control, and removal of barriers to joint and complementary action among U.S. government departments and agencies. The wall [between law enforcement and intelligence activities] is gone."). 
not be used to erase all these statutory incentives for CIA and FBI cooperation.

The Department of Justice has taken the lead in deciding whether alignment exists between spymasters and prosecutors. The intelligence community, meanwhile, has stayed in the shadows. The U.S. Attorneys' Manual, as noted, errs on the side of caution, not wanting to create unnecessary issues for its prosecutors in criminal cases. As far as the public knows, the intelligence community has no written rules or regulations about alignment. Instead, they depend on the Justice Department to take the lead in handling discovery requests in espionage, terrorism, and other cases involving classified information. This continues to be the case under President Obama.

The relevant portion of the U.S. Attorneys' Manual, written before $9 / 11$, states that alignment exists if the intelligence community has "actively participa[ted]" in the investigation or the prosecution of a particular case. ${ }^{147}$ What active participation means, however, very much depends on point of view. Spymasters, not wanting information, personnel, or sources and methods to be pulled into court, have an interest in denying that circumstances constitute active involvement. Prosecutors, under the same circumstances, might argue that active involvement exists.

Prosecutors, to be sure, recognize that not every interaction between agencies is alignment. The U.S. Attorneys' Manual reminds them that, for alignment to exist, the intelligence community's role must exceed "providing mere tips or leads based on information generated independently of the criminal case." 148 Or, as Fredman noted in his article, the CIA may pass off an informant to the DEA so that the law enforcement agency conducts the interview, writes the report, and takes custody of any physical evidence. ${ }^{149}$ If the pass-off occurs at the beginning of an investigation, alignment is unlikely to exist. But passoffs do not take care of all problems.

Reassessing how alignment works requires new thinking about the interaction between spymasters and prosecutors. Rather than speak about intelligence sources and methods in the abstract, a reassessment should actually factor in the human interests of intelligence officers and their sources. Lives and limbs are at stake. As soon as possible, the Director of National Intelligence should task the CIA Director and the Attorney General to review the government's policy on alignment. The findings from their task force could lay the foundations for Congress to amend CIPA by statute. This amendment is of utmost importance since

147 United STATES ATtorneys' Manual, supra note 78, at tit. 9, Criminal ResourCe MANUAL $\S 2052(B)(1)$.

148 Id.

149 See Fredman, supra note 20, at 369. 
the Justice Department has flirted with the idea of handling KSM and other high-level members of al Qaeda by civilian trial.

With the breakdown of the wall between intelligence and law enforcement, the possibility of alignment on criminal cases has increased since $9 / 11$. To keep the system calibrated, a principled means must be applied to make alignment the exception rather than the rule. The outer limits to alignment are easy to state-for Fredman or for me. Alignment does not exist when one FBI agent on the criminal case was on the distribution list for an intelligence report from the CIA. Further, alignment does not exist where a prosecutor, by virtue of changes in the PATRIOT Act, shares grand jury information with the CIA. Alignment is not a game of tag in which one contact between intelligence and law enforcement triggers a prosecutor's discovery obligations. At the other end of possibilities, alignment does exist if the FBI and the CIA's Counterterrorist Center exchange personnel and several documents against a suspected terrorist. Between these clear limits on alignment, there is a wide swath of ambiguity and the potential for reasonable differences of opinion.

The determinations that prosecutors, the courts, and law professors make as to whether alignment exists must not be random. Randomness is much worse than case-by-case analysis. Prosecutors, the courts, and spymasters deserve better guidance. To provide that guidance, the executive branch might synthesize the bits and pieces of advice from the U.S. Attorneys' Manual into a more comprehensive checklist. This could be done through an executive order. Even better, after review by a task force, the White House might propose a congressional stamp on what constitutes alignment. That stamp could actually come through an amended statute that includes appropriate cross-references to the rules of discovery and to CIPA. As long as the two elected branches of government do not cross into constitutional territory, together they can go much farther than Fredman did in guiding the intelligence community and law enforcement into the new century. Moreover, unlike the musings of a law review article, a statute has the force of law.

Brady, although tied to the Fifth Amendment, is not absolute. Congress, if explicit, can trade due process for national security, determining that alignment applies to the CIA only when it has most actively participated in the criminal investigation. That, by itself, would be a significant change. In other words, the statutory framework that was created in 1980 needs remodeling. Once this general fact is accepted, the debate can move on to the specific contours of the new design. My goal is to inspire readers to offer their designs. My design, one of infinite possibilities, reflects a hunch that things have tilted too much against the intelligence community. The Bush Administration, 
for all its faults and abuses, shared this hunch in keeping many terrorism cases out of federal court.

\section{HANDLING Classified INFORMATION AT TRIAL}

Not only does CIPA fail to state a clear standard on alignment, it fails to clarify what happens with classified information at trial. What is relevant and admissible at trial is, in practice, a small subset of the information the parties discover before trial. The defendant's gateway to discovery, so to speak, is much larger than the gateway for use at trial.

Section 6(a) of CIPA allows a court, at an in camera hearing, to determine the use, relevance, or admissibility of classified information. While $\S 6$ spells out procedures, ${ }^{150}$ it does not contain a specific standard for admissibility. ${ }^{151}$ The federal circuits, as a result, have split regarding the appropriate standard. One side acknowledges that the evidence is classified and considers its sensitivity (top secret, secret, or confidential) in determining admissibility. ${ }^{152}$ The other side disregards the sensitivity of the evidence and focuses on relevance. ${ }^{153}$ Each side believes its interpretation of CIPA is correct. If the Supreme Court does not resolve this split, ${ }^{154}$ Congress should adopt the Fourth Circuit's approach to handling secrets at trial.

\section{A. Smith's Heightened Standard for Admissibility}

The Fourth Circuit suggests that judges should consider the classified nature of the evidence when ruling on its admissibility at trial. United States v. Smith 155 was the first to present this approach. The circuit later employed the approach in cases such as United States $v$. Fernandez ${ }^{156}$ and United States v. Zettl. ${ }^{157}$

150 See 18 U.S.C. app. 3 § 6(a), (c), (e) (2006)

151 Scholars agree that Congress intentionally failed to articulate which admissibility standard should be employed when determining the admissibility of classified evidence. See, e.g., Salgado, supra note 47 , at 437 ("Congress simply left it up to the judicial branch to develop the appropriate evidentiary test [for admissibility], and stated only that the current standard was not changed by CIPA."). This is significant in determining legislative intent for the admissibility standard.

152 See infra Part IV.A.

153 See infra Part IV.B.

154 If the Supreme Court intervenes, it too should adopt the Fourth Circuit approach.

155780 F.2d 1102 (4th Cir. 1985) (en banc).

156913 F.2d 148 (4th Cir. 1990). 
Smith, a former intelligence agency employee, was prosecuted for espionage in the Eastern District of Virginia. 158 For $\$ 11,000$, he allegedly gave KGB agent Victor I. Okunev details of five U.S. doubleagent operations. ${ }^{159}$ In his defense, Smith argued that the CIA ordered him to divulge the secrets in an authorized operation. ${ }^{160}$ According to Smith, two men named White and Ishida, who said they were CIA agents, approached him while he was abroad and asked him to do a job for the Agency. ${ }^{161}$ To support his version of the facts, Smith sought to admit classified information at trial to show he had reason to believe White and Ishida were legitimate CIA agents who could order him to disclose information to Okunev. ${ }^{162}$ The government, opposed to Smith's version of facts, claimed that White and Ishida were fabricators and that Smith's offer of proof was a blatant attempt at graymail. 163

The Fourth Circuit, sitting en banc, found that though the evidence was relevant to Smith's defense, it could be excluded from trial because of its classified nature. ${ }^{164}$ The majority recognized a government privilege that protected national security secrets, including intelligence sources and methods. ${ }^{165}$ Further, the Fourth Circuit called on trial courts to balance the government's interest in nondisclosure of classified information against the defendant's need for disclosure. ${ }^{166}$ When weighing these interests, a trial judge should consider the crime charged, the possible defense, the significance of the information, and other relevant factors. ${ }^{167}$ Even so, the government's privilege is qualified, and must give way when the information "is relevant and helpful to the defense of an accused, or is essential to a fair determination of a cause." 168 Smith suggests disclosure is only

157889 F.2d 51 (4th Cir. 1989). Smith and Zettl both involved espionage charges, and the defendants in Fernandez and Smith, both intelligence agency employees at one time, asserted a "CIA defense."

158 United States v. Smith, 592 F. Supp. 424, 427 (E.D. Va. 1984), vacated, 780 F.2d 1102.

159 Smith, 780 F.2d at 1104.

160 Id.

161 Id.

162 Id.

163 Smith, 592 F. Supp. at 434.

164 Smith, 780 F.2d at 1110 . Both the district court and the Fourth Circuit panel found the information to be relevant and admissible. See Smith, 592 F. Supp. at 437; United States v. Smith, 750 F.2d 1215, 1217 (4th Cir. 1984).

165 Smith, 780 F.2d at $1108-09$.

$166 \mathrm{Id}$. at 1107 . The en banc majority remanded the case to the district court to use the balancing standard in ruling on the admissibility of the information. Id. at 1110 .

167 See id. at 1107; cf. Roviaro v. United States, 353 U.S. 53, 62 (1957) (recognizing a privilege to withhold the identity of government informants).

168 Smith, 780 F.2d at 1107 (quoting Roviaro, 353 U.S. at 60-61) (internal quotation marks omitted); cf. Salgado, supra note 47, at 434 ("Under Roviaro, the government cannot prosecute a defendant without disclosing information 'relevant and helpful' to the defendant, regardless of whether or not the government has a weighty interest in maintaining the secrecy of that information."). 
appropriate when the information is essential or necessary to the defense and not "merely cumulative nor corroborative." 169 In other words, decisions under $\S 6$ of CIPA are more complicated than a straight application of relevance under the Federal Rules of Evidence.

The Fourth Circuit was confident that its approach was consistent with Congress's intent in enacting CIPA. ${ }^{170}$ And the court adopted this view even though it conceded that: (1) Congress intended to retain the standards on admissibility; ${ }^{171}$ and (2) substantive law was not otherwise changed. ${ }^{172}$

To justify its balancing test under CIPA, the Fourth Circuit relied heavily on Roviaro $v$. United States, ${ }^{173}$ a Supreme Court decision that recognized the government's "informant privilege" in criminal cases. ${ }^{174}$ The Smith court reasoned that Roviaro allows the government to withhold the identity of an informant from the defendant to protect the safety of the informant and to aid law enforcement; likewise, the government may withhold secrets from defendants to protect an intelligence agency's sources and methods. ${ }^{175}$ The informant's privilege, as the Supreme Court had made clear, encourages people to report criminal activity by ensuring their safety as law enforcement sources. ${ }^{176}$ The same analysis applies to protecting intelligence sources. ${ }^{177}$ To emphasize this point, the Smith court identified the

169 See Smith, 780 F.2d at 1110 (citing Harley v. United States, 682 F.2d 1018, 1021 (1982); Rugendorf v. United States, 376 U.S. 528, 535 (1964); Scher v. United States, 305 U.S. 251,254 (1938)); cf. United States v. Lopez-Lima, 738 F. Supp. 1404, 1411 n.7 (S.D. Fla. 1990) ("The Fourth Circuit declined to establish a 'rigid rule' for the proper balance, stating that it would vary from case to case depending on the crime charged, how essential the information was to the defense, and whether the information was merely cumulative or corroborative." (citing Smith, 780 F.2d at 1110)).

170 Smith, 780 F.2d at $1106 \mathrm{n} .8$.

171 Id. ("[The Senate] report provides ... 'on the question of a standard for admissibility of evidence at trial, the committee intends to retain current law." (quoting SENATE REPORT, supra note 21 , at 8 , reprinted in 1980 U.S.C.C.A.N. at 4302 )).

172 Id. at 1106 ("No new substantive law was created by the enactment of CIPA.").

173353 U.S. 53.

174 See Shea, supra note 44, at 694 ("The Roviaro balancing test was first applied to questions of admissibility of evidence at trial by the Fourth Circuit in United States v. Smith."); see also Salgado, supra note 47, at 440-41 ("[T] he court cited Roviaro as authority, claiming that it was not extending that holding.").

175 Smith, 780 F.2d at 1108 . According to the Smith court:

The government interest protected by nondisclosure [in both cases] is analogous. The government has a substantial interest in protecting sensitive sources and methods of gathering information. The gathering of such information and the methods used resemble closely the gathering of law enforcement information. The confidentiality of sources and the methods used in both instances are critical. Persons who supply information to the government regarding matters taking place in foreign countries are likely to be located outside the United States. Their safety would immediately be placed in jeopardy if their identity were made public.

Id.

176 See id. at 1107.

177 See id. at 1108 
illogic of a privilege that protected domestic informants but not foreign informants. ${ }^{178}$ In sum, the Fourth Circuit held that a national security privilege existed when CIPA was passed, although the government had not yet invoked the privilege. ${ }^{179}$

While the Fourth Circuit's view of $\S 6$ is in the minority among federal circuits, ${ }^{180}$ its analysis is quite significant. Even courts that disagree with the Fourth Circuit on $\S 6$ have paid attention to the Smith analysis. ${ }^{181}$ Many circuits-even those that reject the Smith balancing test at $\S 6$ (a) hearings on the use and admissibility of information at trial-apply a variation of Smith to $\S 4$ decisions on whether classified information must be provided to the defendant in discovery. ${ }^{182}$ Because the CIA's headquarters are in Northern Virginia, many cases that involve CIPA - espionage and otherwise-are prosecuted in the Fourth Circuit. Indeed, the Fourth Circuit's consonance with intelligence

178 See id. at 1109 . The court noted:

To give the domestic informer of the police more protection than the foreign informer of the CIA seems to us to place the security of the nation from foreign danger on a lower plane than the security of the nation from the danger from domestic criminals. In our opinion the national interest is as well served by cooperation with the CIA as with the domestic police. Id.

179 See id. The Smith court explained that, even before CIPA, the prosecution could have invoked the privilege at trial; CIPA's basic change was that it required the assertion of the privilege and the application of the balancing test before trial. In fact, the court reasoned that "[a]doption of Smith's argument would result in a substantive change in the law of evidence, exactly what Congress said CIPA was not designed to do." Id.

180 See infra Part IV.B.

181 See, e.g., United States v. Libby, 453 F. Supp. 2d 35, $41-42$ (D.D.C. 2006) (explaining Smith's holding and reasoning); United States v. Cardoen, 898 F. Supp. 1563, 1571 (S.D. Fla. 1995) (delineating the Smith test but choosing the approach of the district court judge in United States v. Lopez-Lima), aff"d sub nom. United States v. Johnson, 139 F.3d 1359 (11th Cir. 1998); United States v. Lopez-Lima, 738 F. Supp. 1404, 1411 n.7 (S.D. Fla. 1990) (laying out the development and the use of the Smith test in the Fourth Circuit).

182 For the discovery stage, the First, Fourth, and Ninth Circuits have adopted an approach that balances the government's need for secrecy against a defendant's interest in disclosure. See, e.g., United States v. Fernandez, 913 F.2d 148, 154 (4th Cir. 1990) (noting that Smith requires the trial court to take "cognizance of both the state's interest in protecting national security and the defendant's interest in receiving a fair trial"); United States v. Sarkissian, 841 F.2d 959, 965 (9th Cir. 1988) ("On issues of discovery, the court can engage in balancing."); United States v. Pringle, 751 F.2d 419, 427-28 (1st Cir. 1984) (affirming a district court determination that national security would be damaged if classified materials were handed over to the defendant). In contrast, the Fifth Circuit simply requires that the evidence be helpful, as well as relevant to the defense, before disclosure of classified information is required in discovery. United States $v$. Varca, 896 F.2d 900, 905 (5th Cir. 1990) ("[T] he government is not required to provide criminal defendants with information that is neither exculpatory nor, in some way, helpful to the defense."). The District of Columbia Circuit uses a higher standard of relevancy-the information must be relevant and helpful as required by the Roviaro test-but it has "neither adopt[ed] nor reject[ed] the balancing test set forth in Smith." United States v. Yunis, 867 F.2d 617, 625 (D.C. Cir. 1989); see also United States v. Mejia, 448 F.3d 436, 457 n. 18 (D.C. Cir. 2006) ("As in Yunis $I$, we also need not consider whether, if the information were helpful, it could nonetheless be withheld if 'the government's need to keep the information secret' outweighed the 'defendant's interest in disclosure."'). 
interests may cause the Justice Department to file charges in the Eastern District of Virginia instead of other possible venues.

\section{B. Other Approaches to Admissibility}

Circuits that reject the Fourth Circuit's balancing test at trial apply various analyses. 183 The Eleventh Circuit, for example, ruled that when determining whether information was material or not, a court should ignore the classified nature of the information. ${ }^{184}$ For courts that do not engage in balancing, $\S 6(\mathrm{a})$ hearings concerning the use, relevance, or admissibility of classified information consist of several determinations. ${ }^{185}$ To begin, the court determines whether the proffered defense is viable. ${ }^{186}$ If so, the defendant has the burden of showing that the classified information is relevant to the defense. ${ }^{187}$ In determining relevance, the court simply considers the information under Rules 401 and 402 in the Federal Rules of Evidence. ${ }^{188}$ Finally, because not all relevant information is admissible, the court determines if the proffered information should be excluded as unfairly prejudicial, misleading, or confusing under Federal Rule of Evidence 403.189 Again, the burden

183 The Second Circuit does not apply a balancing test. See, e.g., United States v. Wilson, 750 F.2d 7, 9 (2d Cir. 1984). But see United States v. Aref, 533 F.3d 72, 79-80 (2d Cir. 2008) (adopting the Rovario standard to determine whether the government's privilege must give way in a CIPA case). The Ninth Circuit does not identify the opposing approaches or cite the Smith decision, but does not explicitly engage in balancing. See, e.g., United States v. Miller, 874 F.2d 1255, 1276 (9th Cir. 1989); United States v. Clegg, 846 F.2d 1221, 1223 (9th Cir. 1988). The District of Columbia Circuit and Eleventh Circuit both strongly reject the Smith approach. See Libby, 453 F. Supp. 2d at 42 ("It is Smith's balancing mandate which this court cannot accept."); United States v. Baptista-Rodriguez, 17 F.3d 1354, 1364 (11 th Cir. 1994) ("[T]he district court may not take into account the fact that evidence is classified when determining its 'use, relevance, or admissibility."'); Cardoen, 898 F. Supp. at 1571, aff'd sub nom. Johnson, 139 F.3d 1359 ("The Court... declines to adopt the additional Fourth Circuit balancing test in determining the relevance and admissibility of classified information."); Lopez-Lima, 738 F. Supp. at 1407, 1411 n.7 ("Prior Eleventh Circuit decisions indicate that, when making relevancy and admissibility determinations under $\S 6(\mathrm{c})$, a district court must apply the general relevancy standard of F.R.E. 401."); cf. United States v. Anderson, 872 F.2d 1508, 1514 (11th Cir. 1989) (holding that the ordinary rules of evidence, namely 401 and 403, should be used to determine admissibility under CIPA); United States v. Juan, 776 F.2d 256, 258 (11th Cir. 1985) (applying F.R.E. 401 to conclude that defendant's offer of proof of prior relationship with government agencies was admissible and therefore wrongly excluded by the district court judge).

184 Baptista-Rodriguez, 17 F.3d at 1364.

185 See, e.g., Cardoen, 898 F. Supp. at 1570-71.

$186 \mathrm{Id}$. at 1570.

$187 \mathrm{Id}$.

$188 \mathrm{Id}$. at 1571.

$189 \mathrm{Id}$. Relevant information can be excluded in jurisdictions that follow the "straight relevance" approach. Some cases have found that, given the controversial character of counterintelligence operations, information purporting to show the defendant acted under CIA authority when he committed the prosecuted acts is prejudicial, and that this prejudice substantially outweighs the evidence's probative value. See, e.g., United States v. Anderson, 872 F.2d 1508, 
rests on the defendant to show that the probative value is not substantially outweighed by negative factors. ${ }^{190}$ Throughout these determinations, the court refrains from considering whether the information is classified or vital to national security. ${ }^{191}$ The court, in this manner, reads the Fourth Circuit's Smith balancing out of the analysis. ${ }^{192}$

While the Eleventh and D.C. Circuits expressly reject the Smith balancing test, the best arguments against balancing come from Smith itself. ${ }^{193}$ The district court opinion and the two appellate opinions by Judge John Butzner-one for a Fourth Circuit panel and one in dissent-all together provide valid criticisms of the en banc approach. ${ }^{194}$ Judge Butzner interpreted congressional statements that "nothing in the conference [committee bill] is intended to change the existing standards for determining relevance and admissibility" to mean that judges should look only to Rules 401,402 , and 403 of the Federal Rules of Evidence to determine the admissibility of classified information. ${ }^{195}$ Criticizing what he saw as Smith's expansion of the informant's privilege, Judge Butzner argued that the Roviaro standard was not appropriate for CIPA because Congress had contemplated and rejected Roviaro during CIPA's legislative history. 196 Roviaro, Butzner said, dealt with the discovery, not the admissibility of information

1519 (11th Cir. 1989) (concluding classified information that supported defendant's CIA defense was inadmissible under F.R.E. 403 because it would divert the jury's attention from the charges).

190 Cardoen, 898 F. Supp. at 1570-71.

$191 \mathrm{Id}$. at 1571.

192 See supra note 183 and accompanying text.

193 Cf. Salgado, supra note 47, at 440-41 (describing Judge Butzner's dissent from the en banc decision). In rejecting the Smith balancing test, the Libby court relied on Judge Butzner's dissent. See United States v. Libby, 453 F. Supp. 2d 35, 42 (D.D.C. 2006).

194 For the district court opinion, see United States $v$. Smith, 592 F. Supp. 424 (E.D. Va. 1984). For Judge Butzner's panel decision, see United States v. Smith, 750 F.2d 1215 (4th Cir. 1984). For Judge Butzner's dissent from the en banc decision, see United States v. Smith, 780 F.2d 1102, 1111 (4th Cir. 1985) (en banc) (Butzner, J., dissenting).

195 See Smith, 750 F.2d at 1217 n.4 (interpreting H.R. REP. No. 96-1436, at 12 (1980), reprinted in 1980 U.S.C.C.A.N. 4307, 4310). Other courts have made similar points. See United States v. Baptista-Rodriguez, 17 F.3d 1354, 1364 (11th Cir. 1994) (interpreting Congressional intent to require that " $[t]$ he relevance of classified information in a given case is governed solely by the well-established standards set forth in the Federal Rules of Evidence."); United States v. Wilson, 586 F. Supp. 1011,1013 (S.D.N.Y. 1983) ("Both documentary and testimonial evidence containing classified matter may be admitted if in conformity with the Federal Rules of Evidence."). Note that the Smith en banc opinion also cited such statements but argued the government's privilege and the balancing test were part of the existing standard. Smith, 780 F.2d at 1107.

196 Smith, 780 F.2d at 1111-12 (Butzner, J., dissenting) ("Congress was aware of the government's desire to impress on pending legislation the standard of admissibility of classified evidence derived from Roviaro...."); see also Libby, 453 F. Supp. 2d at 40 ("[The balancing] standard was rejected by Congress."). But see Salgado, supra note 47, at 437 ("Congress knew that rejecting the administration's language would not necessarily preclude courts from using the Roviaro standard. Congress simply left it up to the judicial branch to develop the appropriate evidentiary test, and stated only that the current standard was not changed by CIPA."). 
already in the defendant's possession. ${ }^{197}$ Judge Butzner was more inclined to agree with the trial court's observation that "[a] court is illequipped to determine, and a defendant [is] without means to challenge, the extent to which disclosure of particular items of classified information would damage the national security." 198 Therefore, it would be inappropriate, if not impossible, for the court to weigh the national security interest in a $\S 6(a)$ hearing.

Many judges and scholars, in opposition to the views expressed in this Article, agree with Judge Butzner. In particular, one scholar argues that CIPA precludes an informed judicial decision at the $\S 6(\mathrm{a})$ hearing. ${ }^{199}$ By CIPA's terms, the government may neither explain the basis for classification nor the potential damage to national security from disclosure until: (1) the $\S 6$ (a) hearing is complete; (2) a court determines the information is admissible; and (3) the government moves for substitution or summaries under $\S 6(\mathrm{c}) .{ }^{200}$ Because the court does not have what it needs to conduct the balancing test during a $\S 6(\mathrm{a})$ hearing, so the argument goes, it should not be required to do so. ${ }^{201}$

\section{The Smith Balancing Test Since 9/11}

As already noted, some cases after $9 / 11$ have refused to apply the Smith balancing test for $\S 6(\mathrm{a})$ admissibility. ${ }^{202}$ Until CIPA is updated, these precedents stand as obstacles to bringing terrorism cases into federal court. Nonetheless, the Obama Administration apparently concluded that these obstacles were not insurmountable when it designated KSM for trial in civilian court.

Even in the Fourth Circuit, Smith is being undermined. In United States $v$. Rosen, ${ }^{203}$ officials of a pro-Israel lobbying organization were charged in the Eastern District of Virginia with conspiring to commit

197 Smith, 780 F.2d at 1112 (Butzner, J., dissenting). As the Libby court explained, Roviaro and its progeny "stand solely for the proposition that a balancing must be employed before the discovery of classified information may be required. ... Roviaro was not intended to 'exclude the introduction of relevant evidence known to the defendant."' Libby, 453 F. Supp. $2 \mathrm{~d}$ at 42 (quoting Smith, 780 F.2d at 1112 (Butzner, J., dissenting)).

198 Smith, 592 F. Supp. at 436. The district court also asserted that, because the interests of the nation always outweigh a defendant's interests, balancing is dangerously loaded against individual justice. Id.

199 Salgado, supra note 47, at 441-42.

200 See id.

201 Id.

202 See, e.g., Libby, 453 F. Supp. 2d at 40-44 (arguing that since Congress considered and rejected a heightened relevance standard when passing CIPA, $\S 6(a)$ implicitly precludes adopting a common law, classified information privilege with a standard of relevance stricter than F.R.E. 401); see also infra Part IV.B (discussing other courts that have ignored the information's classified nature).

203520 F. Supp. 2d 786 (E.D. Va. 2007). 
espionage by transmitting information related to the national defense to individuals not entitled to receive it. ${ }^{204}$ The government alleged that they came by this information not by their own spying but through a willing source in the Department of Defense. Pursuant to CIPA, the government asked the court to allow the use of summaries, redactions, and substitutions in lieu of classified information at trial. ${ }^{205}$ Of particular importance under CIPA was whether the government possesses a common law privilege in classified information, and, if so, what showing the defendant must make to overcome the privilege. ${ }^{206}$

The Rosen court found the answer to the first part of the question to be clear: Fourth Circuit precedent establishes "that the government has a common law privilege in classified information and that this privilege is not displaced by CIPA."207 But as to overcoming the privilege in the second part, the district court leaned toward the defendants' analysis. The government, relying on Smith, argued that "the privilege is not overcome unless the information as to which the privilege is claimed is "essential to the defense." 208 To counter this argument, the defendants pointed to Moussaoui as additional support for the "relevant and helpful" standard. ${ }^{209}$ The court determined that a defendant has two ways of defeating the government's privilege: showing that the information "is relevant and helpful to the defense ...or is essential to a fair determination of a cause." 210 Shifting from the Fourth Circuit's Smith analysis, the district court also concluded that courts must not engage in any balancing of the government's interest in nondisclosure against the defendant's interest in disclosure. 211 Instead, "the 'balancing' [a court] must conduct is primarily, if not solely, an examination of whether ... the information

204 Id. at 789. Information relating to the national defense is also known as "NDI."

$205 \mathrm{Id}$. at 788 . The government also moved to use the "silent witness rule" with respect to certain classified information. Id. The silent witness rule was described in United States v. Zettl, 835 F.2d 1059, 1063 (4th Cir. 1987) as follows:

[T] he witness would not disclose the information from the classified document in open court. Instead, the witness would have a copy of the classified document before him. The court, counsel and the jury would also have copies of the classified document. The witness would refer to specific places in the document in response to questioning. The jury would then refer to the particular part of the document as the witness answered. By this method, the classified information would not be made public at trial but the defense would be able to present that classified information to the jury.

See also infra Part IV.A.

206 Rosen, 520 F. Supp. $2 \mathrm{~d}$ at 800.

207 Id.

208 Id. (citing United States v. Smith, 780 F.2d 1102,1107 (4th Cir. 1985)).

209 Id. (citing United States v. Moussaoui, 382 F.3d 453, 472 (4th Cir. 2004)).

$210 \mathrm{Id}$. at 800-01 (quoting Moussaoui, $382 \mathrm{~F} .3 \mathrm{~d}$ at 472) (internal quotation marks omitted); see also id. at $801 \mathrm{n} .25$ ("At best, the distinction between the two standards is a fine one, and it is a virtue of the result reached here that it avoids courts having to make judgments based on such fine distinctions.").

211 Id. at 801. 
the government seeks to withhold is material to the defense."212 In light of these rulings and other problems in the case, the government dropped the charges.

In addition to the Eastern District of Virginia, the District of Columbia has had its fair share of CIPA action. In United States $v$. Libby, ${ }^{213}$ the court declined to use the Smith balancing test. ${ }^{214}$ Despite the court's pro-defendant interpretation of CIPA, the jury convicted defendant I. Lewis "Scooter" Libby-Vice President Cheney's former chief of staff-of obstructing justice, making false statements, and committing perjury, all related to the outing of Valerie Plame as a covert CIA employee. ${ }^{215}$ Even so, Libby, as an insider case, did not present the same potential for graymail as handling al Qaeda outsiders in civilian court. Averting disaster on one case does not mean it will be averted on other cases.

Before trial in the Libby case, the parties made filings under $\S 6(\mathrm{a})$ to address the "use, relevance, and admissibility" of classified information at trial.216 Not only did the parties disagree on the evidentiary value of the classified information, they disagreed on the standard for precluding any information from use during trial. ${ }^{217}$ The defense argued that the court must "simply apply" the Federal Rules of Evidence while the government argued that the court should engage in a three-step inquiry. ${ }^{218}$ The government said that when the privilege applied, the classified information should be precluded from use in any form at trial unless the court determines: (1) the document is relevant; (2) the document is "helpful to the defense"; and (3) the defendant's interest in disclosure outweighs the government's need to protect the classified information. ${ }^{219}$ Because the court found that neither legislative history nor case law supported the government's three-step proposal, the court rejected it. 220

The D.C. District Court's interpretation of CIPA, to be sure, was not unreasonable. During congressional hearings that preceded CIPA's enactment, the Justice Department sought a heightened standard for

212 Id. (quoting Moussaoui, 382 F.3d at 476). The court noted: "[T] he government may propose substitutions, which may be accepted if fair to defendants, or if not accepted, the government may nonetheless refuse to allow the information's admission at trial, but would be subject to an appropriate sanction." Id. at 801-02 (citing 18 U.S.C. app. $3 \S 6(\mathrm{c})$, (e) (2006)).

213453 F. Supp. 2d 35 (D.D.C. 2006).

214 Id. at 42.

215 Government's Sentencing Memorandum at 1, United States v. Libby, 453 F. Supp. 2d 35

(D.D.C. 2006) (No. 05-394), 2007 WL 2478128.

216 Libby, 453 F. Supp. $2 \mathrm{~d}$ at 37.

217 Id. at 38 .

$218 \mathrm{Id}$.

$219 \mathrm{Id}$.

$220 \mathrm{Id}$. at 40. 
admissibility of classified information. ${ }^{221}$ The Department, set on that goal, asked for language that made classified information admissible only if "relevant and material."222 (Contrast the government's proposal of "material" with Libby's proposal of "helpful.") The court noted that Congress rejected the government's proposed standard, making clear that "[n]othing in [CIPA] is intended to change the existing standards for determining relevance and admissibility." 223 The court thus held that the Federal Rules of Evidence alone determine the admissibility of classified information at trial.

Despite these recent cases, Smith provides a better balance between the interests of the intelligence community and the rights of a criminal defendant. Even those courts that claim to make $\S 6$ decisions under a straight application of the Federal Rules of Evidence can reach the Smith result through a sleight-of-hand. The Federal Rules of Evidence, after all, rest on the foundation of common law privileges and are flexible enough to accommodate various interests in doing justice. Courts outside the Fourth Circuit can manipulate their analyses under Rules 401, 402, and 403 to achieve what they perceive as fair results.

Having al Qaeda cases in civilian court should prod changes to CIPA itself and to practices under CIPA. Pure civil libertarian arguments should be tempered for the new era. Congress, for a start, should amend CIPA to clarify that all courts should apply Smith. The difference between Smith and other holdings, all nuances aside, is not so great that it implicates a fundamental right to due process. Courts that give defendants the benefit of straight relevance under $\S 6$ of CIPA do so not as a matter of constitutional law, but as statutory interpretation, clouded or guided by their own notions of fairness in criminal trials.

Congress, to be clear, has room to act. If more cases are to be brought from the dark side under President Obama, some accommodations should be made to the intelligence community. Up front, the necessary adjustments to CIPA can be made more quickly and clearly through an amendment to the statute rather than case-by-case tinkering with the law. Congress should now give the Justice Department the heightened standard of admissibility that was denied when CIPA was first enacted.

222 Id. (internal quotation marks omitted).

223 Id. at 38 (quoting HOUSE REPORT, supra note 59, at 12, reprinted in 1980 U.S.C.C.A.N. at 4310) (alteration in original). 


\section{OTHER ADJUSTMENTS FOR TERRORISM TRIALS}

Intelligence officers, fearing exposure to foreign intelligence services and to other dangers, keep their distance from public trials. They do not want the world to know they have been conducting espionage for the United States; they and their human sources would be at risk. Every so often, however, justice can only be done by hearing from an intelligence officer or someone else from the secret world. A witness may be needed to authenticate a piece of evidence or to solve a hearsay problem. So at times the CIA gives in to the Justice Department. But if we are to encourage prosecuting terrorism cases in civilian courts, some accommodations should be made to the intelligence community.

\section{A. Closed Proceedings, Jury Selection, and Special Witnesses}

Our perceptions and our practices should be updated for terrorism trials. Under an old-fashioned view of the Bill of Rights, closing portions of a criminal trial is shocking. The American trial process emphasizes transparency, and almost all American courts have galleries to welcome the media and the public. Indeed, transparency is one check on abuses. Transparency, however, should be balanced against the potential costs of exposing classified information to the public in the courtroom.

The public's First Amendment right to watch a civilian trial and the suspected terrorist's Sixth Amendment right to confront his accusers are not absolute. As with many other constitutional rights, these two rights can be calibrated to accommodate other interests and concerns. In terrorism cases, national security is part of a balance in which protecting intelligence sources and methods is a vital interest. To protect intelligence officers, courts have gone step by step from silent witnesses, to disguises, to pseudonyms, to screens behind which witnesses conceal themselves. These practices are precursors to closing the gallery and excluding the public for a witness or two during trial.

In terrorism cases, the public's right to watch the trial and the defendant's right to a fair trial must be calibrated to special circumstances. In other cases, the identities of informants have been protected and juvenile victims have been spared from looking their 
alleged abusers in the eye. ${ }^{224}$ Congress, by updating CIPA, should now give federal courts a boost in protecting intelligence sources and methods. Congress should provide the intelligence community the same care and respect courts provide to tipsters in organized crime cases and to juvenile victims in sexual assault cases.

When compared to substituted evidence under CIPA (or dismissed civil cases under the state-secrets privilege), closing portions of a criminal trial is not so shocking. Judges, exercising the discretion CIPA now grants them, might propose closing portions of criminal trials to accommodate the intelligence community's interests in protecting very sensitive information. Or more cautious judges might wait for Congress to amend CIPA so that closed portions are more explicitly contemplated, namely through a witness who testifies only in front of the judge, jury, and the parties. The gallery would remain empty for that part of the trial. To reduce a prosecutor's temptation to dress up an ordinary case in national security garb, the Attorney General's approval might be required on any request for closed proceedings. Given a willingness to adjust CIPA, there are many ways to do justice in cases involving suspected terrorists.

In addition to closing portions of a trial, a court might allow the government to do a cursory vetting of the venire during jury selection to make sure there are no obvious security risks in the form of a known or a suspected agent of a foreign power. Those potential jurors who pose a security risk could then be excused from the venire for cause. (I assume, without adding pages of text, that this excusal does not run afoul of the Sixth Amendment and other constitutional provisions.) Although the government cannot vet people to the top-secret level in a day or so, when necessary, the government can vet to the secret level in a very short time. The goal for terrorism cases would be a jury cleared to receive classified information.

New protections in CIPA cases might actually result in a corresponding openness by prosecutors toward defendants. The intelligence community, working with prosecutors, might be more willing to allow a closed portion of a trial to delve into classified areas because, compared to a completely open trial, fewer people would be privy to the information. And our intelligence community would be reasonably sure that foreign intelligence services would not be listening to the proceedings. What the media and the public lose in transparency

224 See Maryland v. Craig, 497 U.S. 836, 852 (1990) (holding that, if the government makes an adequate showing of necessity, protecting a child witness from the trauma of testifying in a childabuse case is an important enough interest to justify the use of a one-way, closed-circuit video feed); see also, e.g., United States v. Yates, 438 F.3d 1307 (11th Cir. 2006); United States v. Bordeaux, 400 F.3d 548 (8th Cir. 2005); United States v. Moses, 137 F.3d 894 (6th Cir. 1998); United States v. Quintero, 21 F.3d 885 (9th Cir. 1994); United States v. Carrier, 9 F.3d 867 (10th Cir. 1993). 
and information, the jury and the defendant would gain in detail and due process. Because the risks to the government from disclosure would not be as great, the balance under $\S 6$ would thus tilt in favor of allowing the defendant to use the information at trial.

Closing part of a trial is not so different from using a "silent witness," a practice judicially approved in certain, but not all, CIPA cases. ${ }^{225}$ Under silent witness practice, the gallery stays open and the parties speak in code, referring to Country A and B or Person X and Y.226 In these circumstances, what usually makes the information classified is the particular connection, not the general fact a country or a person is involved. The judge, jury, and defense team are given a key that matches Countries A or B to, say, France or North Korea, and Persons $\mathrm{X}$ or $\mathrm{Y}$ to Mr. Jones and Ms. Smith. The transcript for the proceedings, which only refers to the code letters from the written key, is not classified. The classified information is thus shared with judge, jury, and the defense, but not with anyone else in the courtroom.227 To the foreign intelligence officer in the gallery, it is as if that part of the proceeding is taking place in an unknown language. Just so, CIPA can be adjusted to acknowledge and to approve silent witnesses in special cases.

Another way to protect the intelligence officer is the use of disguises. In the Jose Padilla trial in Miami, the court allowed one CIA officer to testify in the disguise of glasses and a beard.228 Testimony from this officer, who worked at a covert site in Afghanistan, was necessary for the government to establish the chain of custody for a

225 See, e.g., United States v. Zettl, 835 F.2d 1059, 1063 (4th Cir. 1987) (generally describing the "silent witness rule," which was not objected to by defense counsel during trial). But see United States v. Abu Ali, 528 F.3d 210 (4th Cir. 2008) (expressing no opinion as to the constitutionality of the silent witness rule as described in Zettl but holding that allowing the jury to see classified information that has been withheld from the defendant violates the Confrontation Clause of the Sixth Amendment); United States v. Rosen, 487 F. Supp. 2d 703, 710 (E.D. Va. 2007) (prohibiting use of the silent witness rule because, "given the strong presumption ... that trials will be open and that evidence will be fully aired in public, CIPA's silence about whether 'substitutions' and 'excisions' can be made available to the public and jury on different terms should be interpreted as a prohibition on doing so").

226 See Rosen, 487 F. Supp. 2 d at 708 n.5. The Rosen court noted:

It appears the Fourth Circuit in United States $v$. Zettl coined the term "silent witmess rule" and described it as follows: "[U]nder such a rule, the witness would not disclose the information from the classified document in open court. Instead, the witness, would have a copy of the classified document before him.... [He] would refer to specific places in the document in response to questioning. The jury would then refer to the particular part of the document as the witness answered."

Id. (alteration in original) (citation omitted).

227 A foreign intelligence officer who happens to be in the gallery would not be privy to the connections during direct and cross-examinations.

228 Robert Timothy REaGan, FED. Judicial Ctr., NATIONAL SECURITy CASE STUdies: SPECIAL CASE-MANAGEMENT CHALLENGES 116 (2010), available at www.fjc.gov/public/ pdf.nsf/lookup/ts100222.pdf/\$file/ts100222.pdf; Abby Goodnough, C.I.A. Officer Testifies He Was Given Qaeda 'Pledge Form' Said to Be Padilla's, N.Y. TIMES, May 16, 2007, at A13. 
Taliban application form obtained by the officer in Afghanistan with Padilla's fingerprints on it. A disguise, of course, limits the jury's full assessment of the witness's demeanor, compromising a defendant's Sixth Amendment right to confront his accusers. Nonetheless, the disguised witness is on occasion a fair balance between the interests of national security and the interests of a fair trial. On balance, the use of disguises is another possible area for codification under CIPA.

In other variations, courts have sometimes allowed intelligence officers to testify under pseudonyms and have considered allowing officers to testify behind screens. ${ }^{229}$ If the defendant and the defense counsel do not know an officer's true name or identity, they are limited in how much information they can prepare for cross-examination at trial, again raising Sixth Amendment concerns. Those concerns, however, can reasonably be addressed in CIPA practice.

\section{B. The Constitution and Closed Trials}

Whether portions of a trial are closed, the silent witness practice is adopted, or witnesses are allowed to testify in disguises, pseudonyms, or behind screens, the government must continue to comply with the Constitution. The constitutional requirements for closing a trial can be met, though. Further, just as the Federal Rules of Criminal Procedure give defendants more rights than the Constitution requires, Congress, as a matter of public policy, can make the test for trial closure stricter than the Constitution requires.

Both the First and Sixth Amendments, as starting points, limit the possibility of closing trials. The First Amendment protects public access-especially the press's - to court proceedings that have "presumptively been a public process."230 Likewise, "the explicit Sixth Amendment right of the accused [to a public trial] is no less protective of a public trial than the implicit First Amendment right of the press and public." 231

The First and Sixth Amendments, however, are not absolute. As to the First Amendment's protection of open trials, Press-Enterprise Co. $v$. Superior Court 232 is the seminal case. In Press-Enterprise, the trial

229 Id. In the Padilla trial, the disguised CIA officer also testified under a pseudonym. Id. But in the trial of Ahmed Ressam, the so-called Millennium Bomber intent on blowing up the Los Angeles airport but arrested off the ferry in Port Angeles, Washington, the judge denied the government's request to allow one witness to testify from a remote location or behind a screen. The government, not willing to expose a source to the public, made do without this witness-and still obtained a conviction. REAGAN, supra note 228 , at 49.

230 Press-Enter. Co. v. Super. Ct., 464 U.S. 501, 505 (1984).

231 Waller v. Georgia, 467 U.S. 39, 46 (1984).

232464 U.S. 501. 
court had closed voir dire to the public. ${ }^{233}$ Press Enterprise moved to open the proceedings, and the prosecutor objected. ${ }^{234}$ The trial court agreed with the prosecution, closing voir dire and refusing to release voir dire transcripts to Press Enterprise. ${ }^{235}$ After trial, the case reached the Supreme Court. There, the Court held that the closure was unconstitutional. ${ }^{236}$ As the Court formulated the First Amendment's protections:

[A] presumption of openness may be overcome only by an overriding interest based on findings that closure is essential to preserve higher values and is narrowly tailored to serve that interest. The interest is to be articulated along with findings specific enough that a reviewing court can determine whether the closure order was properly entered. ${ }^{237}$

Yet Press-Enterprise did not address the Sixth Amendment's guarantee of a public trial. (It is not clear that the same standard should apply to both Amendments.) A defendant's right to a public trial is, after all, connected to a right to a fair trial. And the right to a fair trial should trump the press's First Amendment right to access when, for example, a defendant seeks closure to ensure candid answers from the venire. ${ }^{238}$

The Court offered more guidance about secrecy and trials in Waller v. Georgia. 239 In that case, the Court applied the PressEnterprise standard when the defendant objected to closure of a suppression hearing. ${ }^{240}$ The Court pointed out:

The requirement of a public trial is for the benefit of the accused; that the public may see he is fairly dealt with and not unjustly condemned, and that the presence of interested spectators may keep his triers keenly alive to a sense of their responsibility and to the importance of their functions. ${ }^{241}$

The Court restated Press-Enterprise as a four-part test: First, the party seeking closure "must advance an overriding interest that is likely to be prejudiced, [second,] the closure must be no broader than necessary to protect that interest, [third,] the trial court must consider

\footnotetext{
$233 \mathrm{Id}$. at 503.

$234 \mathrm{Id}$. at 503-04.

235 Id.

236 Id at $510-11$.

237 Id. at 510 .

238 This was the exact issue raised during the first jury trial of an alleged international terrorist arrested after 9/11. United States v. Koubriti, 252 F. Supp. 2d 424 (2003) (holding that the press's First Amendment right of access yielded to the defendants' right to a fair trial and an impartial jury).

239467 U.S. 39 (1984).

240 Id. at 47 .

241 Id. at 46 (quoting In re Oliver, 333 U.S. 257,270 n.25 (1948)) (internal quotation marks omitted).
} 
reasonable alternatives to closing the proceeding, and [fourth,] it must make findings adequate to support the closure." 242

Although the Supreme Court has not yet applied Waller to the evidentiary portion of a trial, the lower courts have. ${ }^{243}$ Further, in a case after $9 / 11$, the court in the Northern District of Illinois closed portions of a hearing for members of the Israeli Security Agency (ISA) who came out from the secret world in United States v. Abu Marzook. ${ }^{244}$ The American charges against defendant Salah included providing material support to Hamas. ${ }^{245}$ The American prosecutors, to prove their case, sought to introduce statements Salah had made while in ISA custody. ${ }^{246}$ Before trial, Salah moved to suppress those statements, claiming they were the fruits of Israeli coercion and torture. ${ }^{247}$ To support their argument that Salah's statements were voluntary, the prosecutors proposed the testimony of the two ISA agents at a suppression hearing. ${ }^{248}$ Moreover, to protect the ISA identities and any sensitive information that might be disclosed, the prosecutors asked the court to close the hearing while the two ISA agents testified. ${ }^{249}$ The press intervened, challenging the motion for closure. 250

The district court analyzed the Abu Marzook proposal for closure under both the First and Sixth Amendments. In addressing Waller's overriding interest prong, the court stressed the government's interest in keeping classified information from being disclosed. ${ }^{251}$ The court said closure would protect the secrecy of intelligence methods and would preserve our nation's working relationship with a foreign intelligence service. ${ }^{252}$ Protecting the identities of the ISA agents was an overriding interest because they, like undercover drug agents, would be put in danger if their identities were revealed. ${ }^{253}$ As a result of this analysis, the court held that Waller was satisfied because the hearing would be closed only during the ISA agents' testimony. ${ }^{254}$ For the suppression

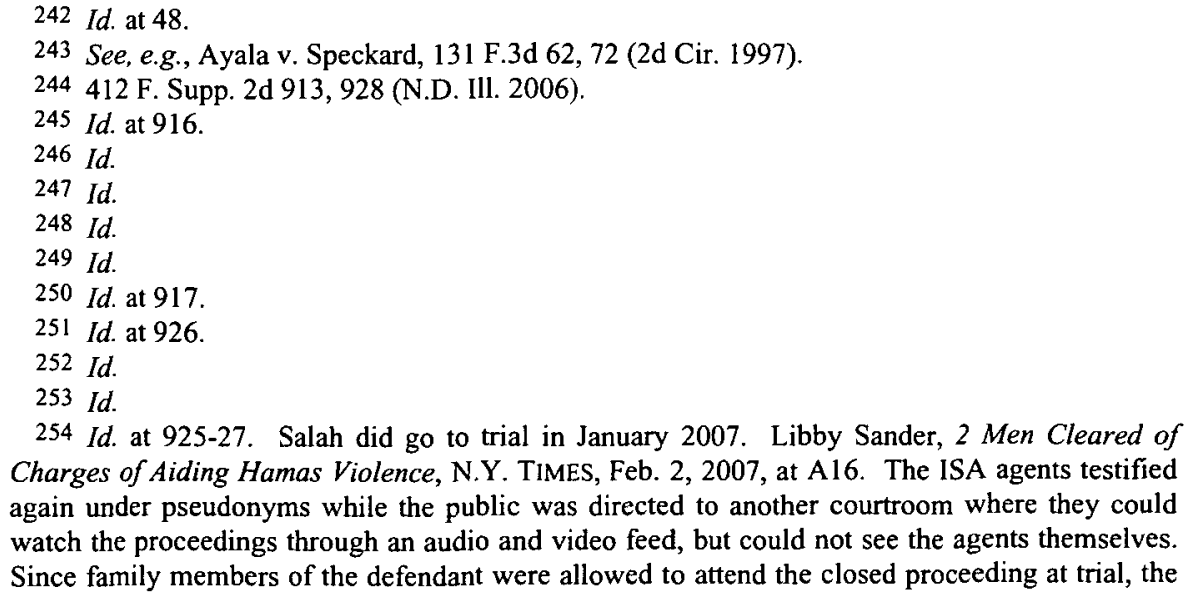
again under pseudonyms while the public was directed to another courtroom where they could watch the proceedings through an audio and video feed, but could not see the agents themselves. Since family members of the defendant were allowed to attend the closed proceeding at trial, the 
hearing, the ISA agents entered the courthouse by a private entrance and were identified in court documents by pseudonyms. But the judge, having agreed to a closed hearing, did not accept the government's request that the ISA agents be able to testify in disguise.

Other precedents support closure. Outside the federal system, New York State has developed procedures for determining if and to what degree a trial may be closed. On habeas review, the Second Circuit has accepted the constitutionality of New York's trial closures on several occasions. ${ }^{255}$ New York convenes Hinton hearings to establish whether closure is appropriate. ${ }^{256}$ The procedure is most often employed to protect the identity of undercover agents in narcotics cases. On this point, the federal courts might learn from their state court cousins. Whatever the setting, intelligence officers deserve to be protected as much as informants.

While statutory language is not yet in place for federal courts to close portions of terrorism cases, at least one court has already closed proceedings in an espionage case. In United States $v$. Pelton, ${ }^{257}$ the defendant was charged with delivering highly classified information to the Soviet Union. 258 The government, for its case in chief, wanted to play classified recordings of wiretaps. ${ }^{259}$ To avoid unnecessary disclosure of classified information, the government sought to play the recordings through headphones to only the jurors, the defense, and the judge. ${ }^{260}$ The press intervened, asking the court to reject the government's plan in light of the press's right of access. ${ }^{261}$ In this case, the court recognized that national security was an overriding interest. ${ }^{262}$ On this variation of silent witness practice, the government's plan passed constitutional muster.

Although courts have already closed portions of trials on their own, Congress should provide courts with specific procedures to decide whether and how to close trials when CIPA is involved. The solution to secrecy and due process should be systematic, not ad hoc. To provide a margin of comfort, Congress might allow closure only when the government shows by "clear and convincing" evidence that the overriding interest will "most likely" be prejudiced, rather than the constitutional standard of "likely to be prejudiced." Congress, in any

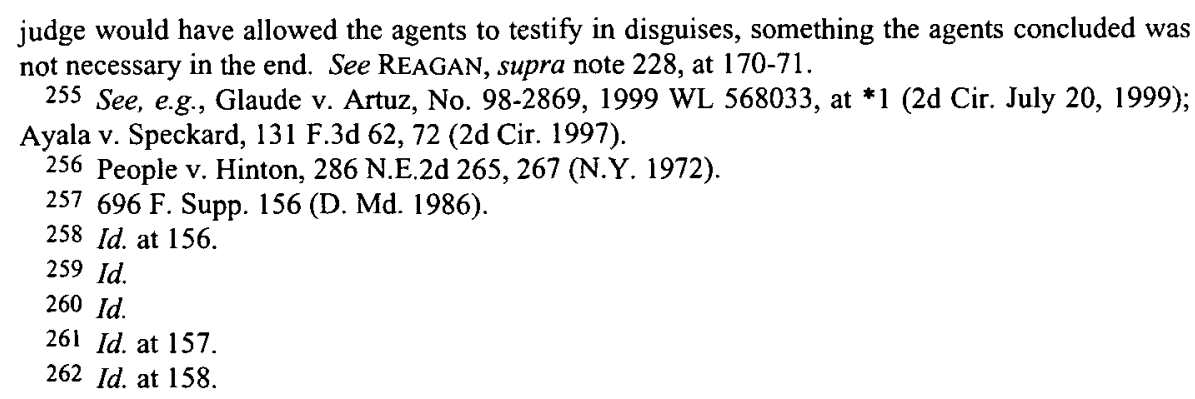


event, should include an escape clause that would preclude closure if the trial court found it would be unconstitutional under the specific circumstances.

Congress might also delineate a $\S 6$ style hearing to determine whether and to what degree closure is appropriate. For that hearing, Congress should lay out a nonexhaustive list of questions to be answered. Does disclosure affect relations with a foreign intelligence service? Would disclosure endanger undercover agents or human assets? As a further check, the Attorney General's authorization might be required. Whatever the checks, by a clearer and more reasonable framework for closing portions of trials, Congress can alleviate some of the complications of trying terrorists in civilian courts while, for the most part, safeguarding the Constitution's guarantee of a public and fair trial.

On closed trials and other areas related to CIPA, the time has come for compromises - and for radical centrism. Long before $9 / 11$, even the staunchest advocates for transparency conceded that national security sometimes tilts the balance in favor of closing trials. ${ }^{263}$ Since some federal courts have already engaged in selective closure, Congress should now address the issue and provide all courts with uniform guidance. Under a proper separation of powers, Congress, not the courts, should fill in the details on closing parts of some trials to accommodate the protection of classified information with the preservation of fair trials after $9 / 11$.

\section{CONCLUSION}

The intelligence community and the law enforcement sector are supposed to be working closely to keep us all safe from terrorists and other dangers. The benefits of this cooperation should not be frittered away by unnecessary burdens in trying suspected terrorists in civilian courts. If the executive branch is to be kept away from the dark side of counterterrorism, the courts, Congress, or a combination of the two should modernize their approach to alignment to $\S 6$ of CIPA and to closed portions of trials.

First, a prosecutor's discovery obligations should apply to the intelligence community only when it has most actively participated in the investigation. When defining "most actively" and in determining who falls within the prosecution unit, all three branches should err

263 Richmond Newspapers, Inc. v. Virginia, 448 U.S. 555, 598 n.24 (1980) (Brennan, J., concurring) (noting that national security may be an example of an overriding interest possibly justifying closure). 
toward non-alignment, ending the creep toward conceding alignment on all cases.

Second, the courts, Congress, or a combination of the two should allow the sensitivity of classified information to affect its use at trial. ${ }^{264}$ On a close call, the court should be less inclined to admit top-secret information than information at a lower level of classification. Further, the more sensitive the information, the more leeway courts should give prosecutors in proposing substitutions and summaries. The common sense that probably fills the gaps of CIPA practice, squeezing around cases and the statute, should be formalized by an update of CIPA.

Third, the courts, Congress, or a combination of the two should allow small portions of trials that involve classified information to be closed to the public. Closed portions of trials are part of the logical and practical extension of silent witness practice. These limited closures allow courts, as a compensating benefit, to lean toward defendants on $\S 6$ decisions as to the use of classified information at trial. By this compensation, the either/or of full disclosure versus complete suppression is traded for a range of options. Indeed, those who do not believe the government should get everything it seeks could argue, as a trade-off, that Congress should actually codify the straight relevance approach for $\S 6$ that goes against the government. So if my approach wins on alignment and on closing portions of trials, the Smith approach from the Fourth Circuit could be sacrificed. For most ventures, two out of three is not bad.

CIPA is showing its age. Even so, because its foundation is solid, it does not require a tear-down as much as a remodeling. In at least three areas-alignment, $\S 6$, and closed portions of trials-our nation deserves a better resolution between the conflicting interests of prosecutors and spymasters.

264 "Sensitivity" is another way of describing the potential damage if the information is disclosed to the public. Depending on the potential damage, information can be top secret, secret, or confidential. 



\title{
Mitchell Hamline Open Access
}

Mitchell Hamline Open Access is the digital archive of Mitchell Hamline School of Law. Its mission is to preserve and provide access to our scholarly activities, for the benefit of researchers and members of the legal community.

Mitchell Hamline Open Access is a service of the Warren E. Burger Library.

open.mitchellhamline.edu

\author{
$\mathrm{MH}$ \\ MITCHELL | HAMLINE \\ School of Law \\ (C) Mitchell Hamline School of Law \\ 875 Summit Avenue, Saint Paul, MN 55105 \\ mitchellhamline.edu
}

